\title{
The Twentieth Century Invention of Ancient Mountains: The Archaeology of Highland Aspromonte
}

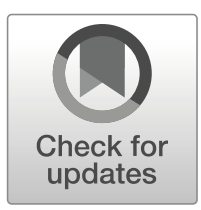

\author{
John Robb ${ }^{1}$ - Meredith S. Chesson ${ }^{2} \cdot$ Hamish Forbes $^{3} \cdot$ Lin Foxhall $^{4}$. \\ Helen Foxhall-Forbes ${ }^{5}$. Paula Kay Lazrus ${ }^{6} \cdot$ Kostalena Michelaki $^{7}$. \\ Alfonso Picone Chiodo ${ }^{8}$. David Yoon ${ }^{9}$
}

Published online: 12 May 2020

C) The Author(s) 2020

\begin{abstract}
The high mountains of the Mediterranean are often considered as refuges of ancient traditions, particularly of pastoralism and brigandage. Is this image true? This paper reports the first systematic archaeological research on Aspromonte, Southern Calabria. Archaeological, cartographic and air photo evidence suggests that people used the high mountains in all periods from the Neolithic onwards. However, early usage was lowintensity and probably for special purposes such as iron-smelting, charcoal-burning and logging; only in the Classical Greek period was there sustained effort at inhabiting higher areas. The real development of the mountains came in the late-nineteenth and twentieth centuries. From the 1920s onwards, there were large-scale, state-fostered projects for economic exploitation of forests, political control of territory, and creation of a recreational landscape. These endeavors tied into modernist ideas of the state, as well as period concepts such as Alpinism and healthy outdoor recreation for city dwellers. Ironically, as soon as these modern efforts made the high mountains accessible, they were assigned a chronotope, and were reimagined as the exemplification of an ancient way of life.
\end{abstract}

Keywords Twentieth century $\cdot$ Mountains $\cdot$ Forests $\cdot$ Pastoralism $\cdot$ Development $\cdot$ Field survey

\section{Introduction: The High Mountains as the Last Refuge of Ancient Traditions}

In 1912, the eccentric English traveller Norman Douglas crossed the Aspromonte massif of Calabria on foot. To him, as to others, ascending the mountains also involved going back in time. In Aspromonte, "one of the last refuges of living Byzantinism"

John Robb

jer39@cam.ac.uk

Extended author information available on the last page of the article 
(Douglas 1938: 387), Douglas admired the trackless mountains and majestic forests deserted of humanity, the bucolic herders harkening back to an ancient, Classical tranquillity. An archaic lawlessness also prevailed, beyond the reach of the state: "Aspromonte, the roughest corner of Italy, is no place for misunderstandings; the knife decides promptly who is right or wrong, and only two weeks ago I was warned not to cross the district without a carbineer on either side of me" (Douglas 1938: 349).

Less poetic observers than Douglas, both Italian and foreign, have consistently depicted Aspromonte in similar terms. Throughout the twentieth century and up to the present, perception of Calabria's high mountains has focused upon two images: survival of a traditional peasant society, particularly of pastoralism, and lawlessness, particularly of brigands. For both images, both local history and public information projects a continuity from present images of rural land use and rural criminality (such as the notorious 'ndrangheta kidnappings using Aspromonte as a hideout in the 1970-80s) back into a deep past.

What is this image based upon? From an archaeological viewpoint, surprisingly little. Historical documentation for settlement and land use in this area is overwhelmingly biased towards inhabited lowland areas below $1000 \mathrm{~m}$. Particularly before the twentieth century, historical records for mountain areas above $1000 \mathrm{~m}$ are almost nonexistent. Archaeological research has potential to remedy this, but virtually all archaeological work in the area has focused on lowland areas, particularly the densely settled coastal strip. There has never been any systematic archaeological exploration of the mountain zones of Aspromonte which would allow us to evaluate how far back and for what purposes humans have actually used these mountains. Mountainous areas present both unique challenges and opportunities for human occupation and unique challenges for archaeological research (Grimaldi et al. 2016); in southern Europe, this is often tied up with the archaeology of prehistoric and historic pastoralism. There is an increasing body of diachronic research studying the changing ways people have used Europe's high mountains, particularly the Alps and Pyrenees, up to the twentieth century, for pastoralism, specialized production, transit, and other uses (Berruti et al. 2016; Carrer 2013; Carrer and Angelucci 2018; Christie et al. 2007; Gassiot Ballbè et al. 2016; Mientjes 2004; Moe and Fedele 2019; Putzer et al. 2016; Stagno 2017; Walsh et al. 2014). These works provide a comparative context for the work presented here. No such work has been done in Aspromonte. This paper presents the results of the first such fieldwork, supplemented by information from textual sources, maps, and aerial photographs. It is the first work in the region to contribute to a growing body of historical archaeology on rural and mountainous areas of Europe, in particular of state intervention and the massive social changes of the twentieth century (Kuijt et al. 2015; Pluciennik et al. 2004; Samuels 2010).

\section{Regional Background and Methods}

Aspromonte, the very tip of the Italian peninsula, is the last outcrop of the Apennines, a mountainous bump about $50 \mathrm{~km}$ across whose provincial capital is Reggio Calabria, on the Straits of Messina (Figure 1). It includes a narrow coastal strip which rises steadily toward an inland massif about $30 \mathrm{~km}$ across. Its highest point is Montalto (1960m above sea level). Virtually all modern and 
historic towns lie below $1000 \mathrm{~m}$ altitude. The single exception, Gambarie $(1350 \mathrm{~m})$ is a twentieth century foundation discussed below. The landscape is strongly zonated by altitude. Roads, railroad lines, and modern settlement are concentrated along the coast, which is hot and dry; in recent decades, the most productive farming here is heavily irrigated cash-cropping for citrus fruits. Traditional Mediterranean farming coincides with a band of historic settlement up to about $1000 \mathrm{~m}$, which is the current viable limit of olive trees. Between $1000 \mathrm{~m}$ and about $1300 \mathrm{~m}$ are rugged mountains interspersed in places with small, moderately level plains or "campi" which offer a well-watered, cooler environment for mixed farming, particularly cereals. From $1300 \mathrm{~m}$ up to the crest of Aspromonte, there is almost no modern or historic settlement, the environment is cool and cloudy with frequent springs and streams, there is considerable snow cover in winter, and the land is thickly forested, mostly with pine and beech. These latter two zones, above $1000 \mathrm{~m}$, are the principal focus of this research.

Since 1997, the Bova Marina Archaeological Project has been exploring the landscape extending inland from the coastal town of Bova Marina; this includes a field survey conducted according to standard Mediterranean field survey techniques. Areas surveyed extend up to about $1200 \mathrm{~m}$ altitude and about $12 \mathrm{~km}$ inland. However, like all archaeological efforts in the area, this survey leaves the higher center of Aspromonte completely uninvestigated. Few sites are known from antiquarian and amateur finds in the high mountains (Picone Chiodo 2005). Thus, in 2014, we began a second field survey, covering a rectangular area extending north-south from Gambarie to Bova, and west-east from Gambarie to beyond Montalto (see Fig. 1).

Surveying a thickly forested, steeply mountainous landscape challenges traditional survey methods. In most places, there is little or no ground visibility, and walking in
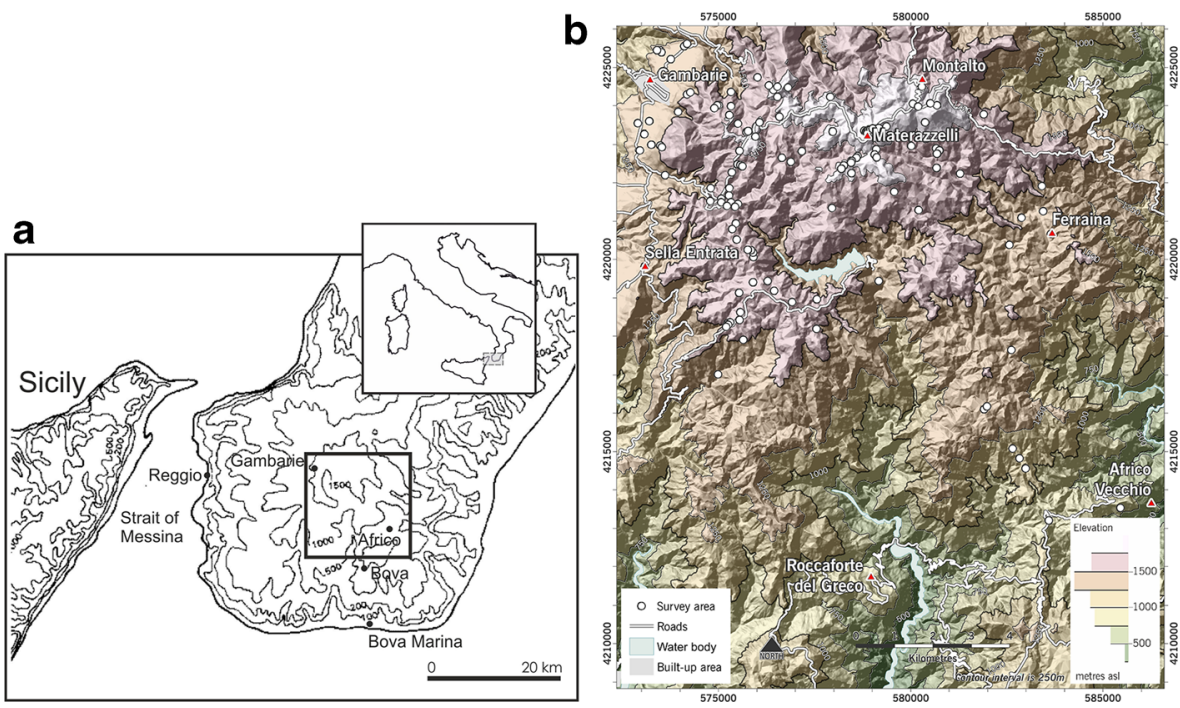

Fig. 1 a. Aspromonte massif in southern Calabria (black box outlines study area). b. Survey areas $(n=195)$; some points represent midpoints of linear areas such as roads and ski slopes (map by D. Redhouse, base data from Tarquini et al. n.d.) 
straight, parallel transects is not possible. Unlike many Mediterranean landscapes which have been intensively frequented for millennia, there is little background artifact scatter. Moreover, intensive, systematic field-walking requires some previous knowledge of the archaeological landscape and invests intensive work in a restricted area; it does not provide an efficient strategy for a first exploration of a large, entirely unknown landscape such as this. In such circumstances, we used methods of less structured reconnaissance, much as recommended by Gassiot Ballbè et al. (2016: 37):

Considering the almost [total] absence of a priori information about the archaeological remains in mountain areas, the most reasonable approach seems to be to carry out extensive, undirected, surveys trying to cover as much territory as possible, identifying and recording as many vestiges as possible. This strategy would create a first set of data about the human occupation of a certain mountainous space, with the possibility of later redirecting the survey toward specific questions/areas/evidence.

We systematically inspected landscape areas chosen according to two criteria:

1. 195 areas were chosen because the ground surface or stratigraphy were visible (Fig. 2a): this included road cuts, unpaved road surfaces, open roadside areas, ski slopes, trails, eroded rocky peaks and clearings, disturbed areas around modern buildings and works, recreational areas, tree throws, and even areas rooted up by wild boars. While this may bias findings towards modern features creating land disturbance, areas which attract modern use such as peaks, pathways and springs may have been equally attractive for ancient people, and modern disturbance often unearths earlier features which would otherwise have remained buried; prehistoric, Classical, and medieval finds were made on hiking trails, roads, springs, picnic areas, and even a military base. Moreover, areas such as eroded forest clearings presumably have an equal chance of yielding finds from all periods.

2. Targeted inspections were made at 40-50 areas where potential features of interest were suggested by maps, aerial photos, toponyms, or discussion with knowledgeable local people. Beyond these, about two dozen further structures were identified satisfactorily in these documentary sources but not visited for practical reasons. These sources allowed us to check changes in forestation, roads, houses, mills, and other structures and features, as well as identifying landscape features such as springs which might attract human use. The principal sources used were:

a. the 1870 IGM (Istituto Geografico-Militare) 1:50000 scale topographic maps (the first topographic maps of the area, made soon after the unification of Italy as a modern state).

b. Royal Air Force air photos held in the National Collection of Aerial Photography (Edinburgh), made in August-September 1943 immediately before the Allied invasion of the Italian peninsula.

c. the 1957 IGM 1:10000 scale topographic maps, the first made using aerial photography, the most detailed available, and a source on land use of that time. 

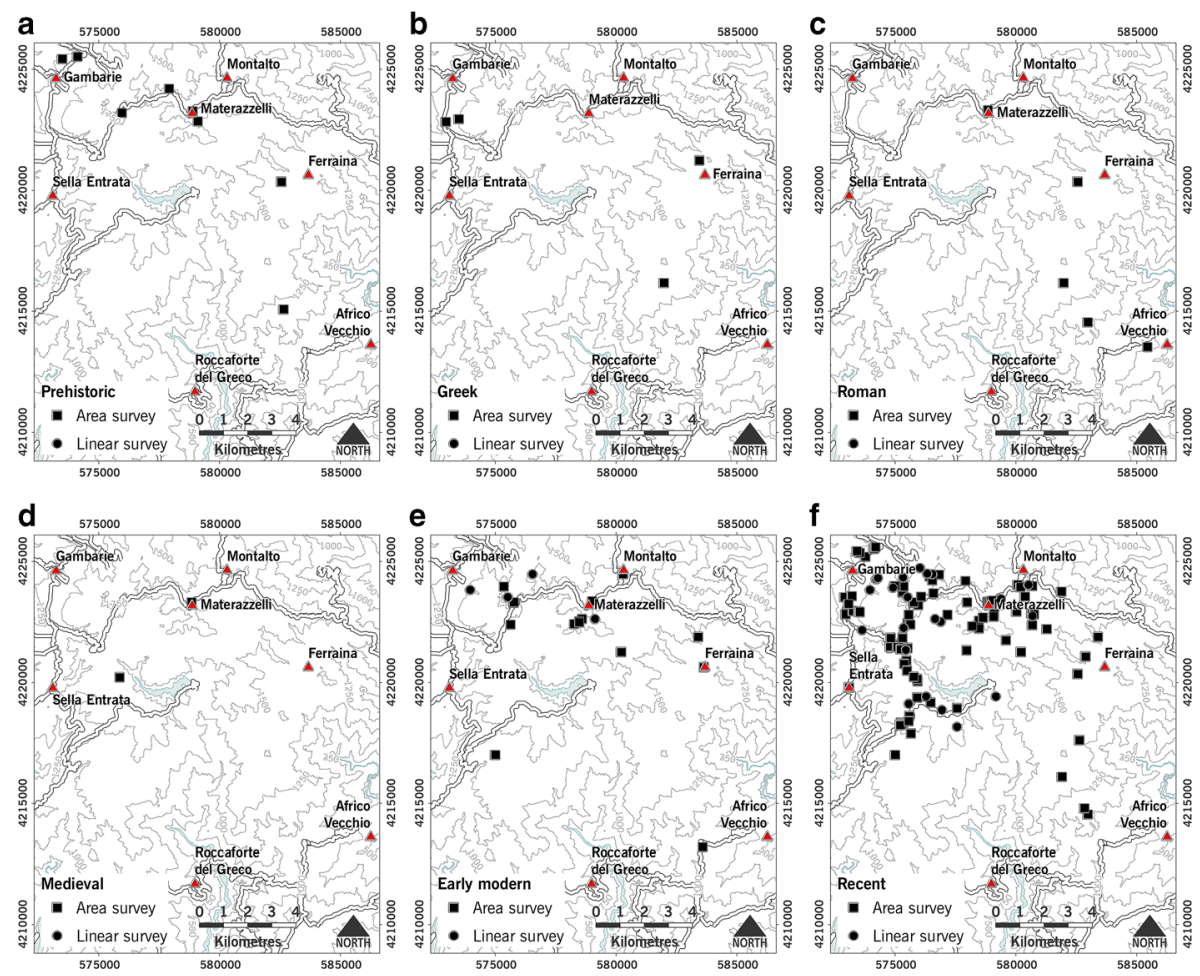

Fig. 2 Survey finds. Unfilled circles indicate areas surveyed with no finds from the period. a. Prehistoric finds. b. Greek period finds. c. Roman period finds. d. Medieval finds. e. Early modern finds. f. Nineteenthtwentieth century finds. Maps by D. Redhouse

d. the 1997 IGM 1:25000 scale topographic maps.

e. 2014-2019 Google Earth aerial photographs.

At each area visited, all visible ground surfaces were examined for archaeological remains. In total about $1.5 \mathrm{~km}^{2}$ of areas such as clearings were walked over our cumulative six weeks of fieldwork, almost all in small, irregular patches. We also walked approximately $50 \mathrm{~km}$ of linear features such as roadsides, unpaved roads, hiking trails, and ski slopes. Finds were identified and registered in the field. We recorded all ceramic finds, metal objects, and architectural remains. Most of the findspots were small scatters of material, sometimes comprising one or a handful of artifacts. To avoid destroying this record, our policy was to record finds in the field (Fig. 3) rather than collect them. For practical reasons, we did not record the numerous recent campfires, scatters of broken glass, and plastic bottles, giving an effective cut-off for our surface finds of probably sometime in the 1970s. By far the most common find was a small handful of eroded modern terracotta sherds, often from water jugs or food vessels, representing short-term use of a particular spot in the last century or so. But enough finds from other periods were found to suggest that the method was effective in assessing archaeological presence generally. 

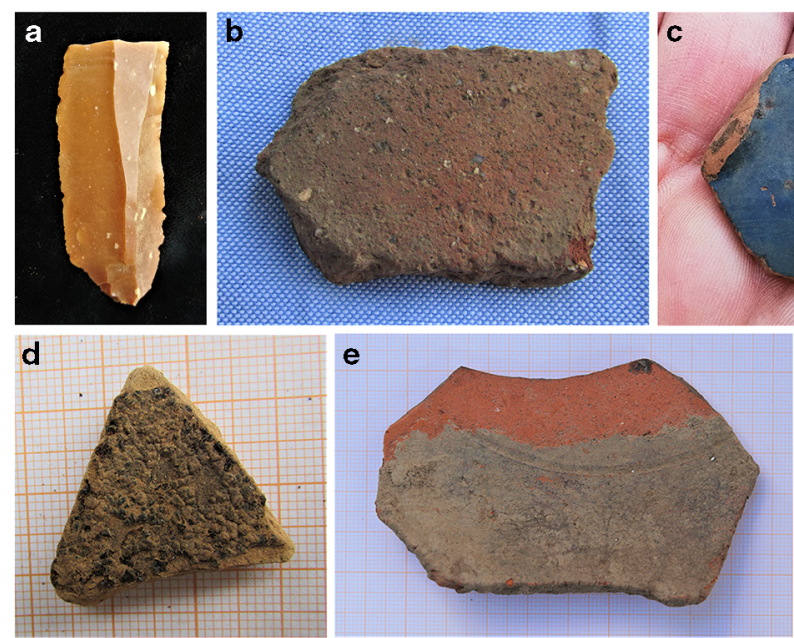
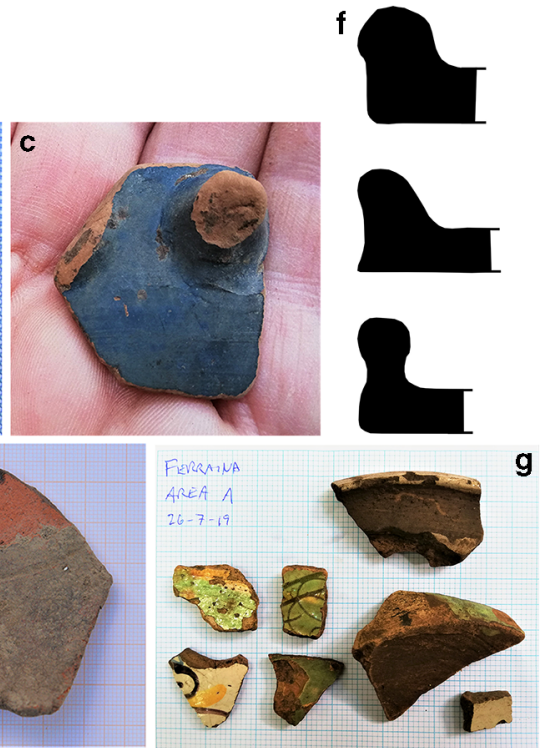

Fig. 3 Surface finds from field survey. a. Neolithic blade made from imported Sicilian flint, Porto Aposcipo. b. Prehistoric pottery, north of Gambarie. c. Greek black-gloss cup fragment, Ferraina B. d. Greek sherd with black crystalline encrustation, possible spring sanctuary site, southeast of Gambarie. e. Roman period African Red-Slip ware, north-west of Africo. f. Late Roman/ early Medieval tile profiles, Materazzelli. g. Early modern wares, Ferraina A iron-working site

This research provides preliminary data. The main risk is of under estimating human presence in periods which have a light archaeological footprint; for instance, where temporary or ephemeral presence results in thin artifact scatters rather than substantial architectural remains or dense artifact scatters. For this reason, we have treated any evidence of human presence as significant; most of our findspots dating to before the early modern period, for instance, are represented by finds of 1-3 artifacts. We have subsequently revisited and rechecked almost all findspots from before the early modern period, and most important undated finds. In almost all cases, this simply confirms both the presence and the sparsity of finds; in a few cases, these have provided further evidence for dating sites. Such sparse finds themselves give testimony of the nature of human presence; for the Greek, Roman and medieval periods, for example, survey findspots are typically characterized by substantial artifact scatters, while in this research they typically yield very few finds, confirming the transient and specialpurpose nature of human occupation of the mountains. While future work will no doubt refine and challenge our findings, these results provide the basis for an initial archaeological account of land use in Aspromonte, which can be used to critique historical images of the area. 


\section{Use of the Mountains: Before the Nineteenth Century}

\section{Prehistoric: Neolithic (6000-3500 BCE) and Bronze Age (2400-1000 BCE)}

Prior to this research, only three prehistoric sites were known in the region of highland Aspromonte studied: a Bronze Age site at Monte Perre (about 1300 m)(Bonfà 2015), an isolated Neolithic axe found somewhere on Monte Basilico (above 1400m [Salerno and Pessina 2004]) and a Neolithic obsidian core found by the Bova Marina Archaeological Project field survey at about $1100 \mathrm{~m}$ in the Campi di Bova. Our survey added six others (see Fig. 2b), including non-diagnostic stone flakes at Nardello and at Caddeo (both above $1800 \mathrm{~m}$ ), a Neolithic blade above Africo (about $1250 \mathrm{~m}$ ), a Neolithic obsidian bladelet and flint blade at Porto Aposcipo (1350 m) (see Fig. 2b, Fig. 3a, b), and possible Bronze Age pottery at two locations north of Gambarie (about 1350m). Possible prehistoric sherds were also found at two other locations. These finds suggest that people in all prehistoric periods used the mountains at least sporadically. Given the steep terrain in which surfaces are often either eroded or buried under colluvium, and the fragile nature of low-fired prehistoric pottery, it is difficult to say much more. But, except for Monte Perre and Porto Aposcipo, all of these are isolated finds; the prehistoric record is sparser here than at lower altitudes which are equally steep and exposed, suggesting perhaps sporadic or special-purpose use of the high mountains.

\section{Greek}

One of the most remarkable aspects of the archaeology of Aspromonte is the series of small, fortified Greek-period sites encircling the massif between 1000 and $1300 \mathrm{~m}$ (Foxhall and Yoon 2016). This highland settlement complements the Greek cities, towns, villages and isolated rural sites thickly populating the lowland coastal strip and forming part of the heartland of Magna Graecia. Beyond the excavated, fortified, largely Greek sites, San Salvatore (located above Bova at 1260m [Foxhall et al. 2010; Foxhall and Yoon 2016]), Serro di Tavola (located above Sant'Eufemia [Brizzi and Costamagna 2010]), and Monte Palazzi (located northwest of Locri [Visonà 2009, 2010]) and the more indigenous Palazzo (located near Zervò, above Oppido Mamertina [Agostino and Sica 2009]), half a dozen others are known (Foxhall and Yoon 2016; Picone Chiodo 2005). Almost all lie near the cultivable plateaus known as campi (1000-1300m). Traditionally, these sites have been interpreted as military outposts built during wars between the Greek cities of Rhegion and Locri, but this interpretation is dubious; they date to many different moments between the Archaic and the Hellenistic, some (e.g., Palazzo) were indigenous sites unaffiliated with Greek cities, and it is anachronistic to suppose that Greek poleis would have maintained formal boundaries or a fixed military presence so far up in the mountains. A more convincing view is that such sites represent fortified settlements established by powerful private families or patron-client networks attempting to exploit mountain resources and the fertile, wellwatered farmlands on the campi plateaus. Although they used Greek-derived material culture, they need not have been "Greek" in ethnic identity in the same ways as the coastal urban centres, but may have represented a range of people from Greek, indigenous and mixed backgrounds (Foxhall and Yoon 2016). 
The highland survey adds substance to this picture by revealing non-fortified Greek sites in the high mountains (see Fig. 2c, Fig. 3c, d). Three sites (Pino di Tommaso at $1390 \mathrm{~m}$, Ferraina B at 1400m, and Monte Basilico 3 at 1350m) may represent unfortified living sites of some kind; the former yielded generic Classical cooking wares, and the latter two diagnostic black-gloss cups. Ferraina B may be associated with industrial production, perhaps of iron. The highest known Greek site to date (on Monte Basilico at $1514 \mathrm{~m}$ ) is probably a Hellenistic rural sanctuary at a mountainside spring $1 \mathrm{~km}$ upslope from settled areas; a sherd from this site with crystalline black encrustation suggests activities such as the tapping and processing of pitch from pine trees. Of all ancient periods, the Greek period represents the only concerted attempt to exploit the mountains, not only through special-purpose sites but through agricultural settlement as well.

The presence of a likely sanctuary site in the high mountains also provides a material manifestation of the ways in which ancient classical culture conceptualized and to some extent romanticized the high mountains as a key element of their cosmos (McInerney and Sluiter 2016). The positive and negative aspects of mountains are documented in many Classical sources (Buxton 2016; König 2016). For Greeks and Romans the mountains were untamed, undomesticated places of both wildness and purity, inhabited by wild people, wild animals and unpredictable supernatural beings who could be helpful, dangerous, or simply present, such as the nymphs believed to inhabit springs. Mountains were places where normal social practices might be put on hold (as in Euripides' Bacchae, where Pentheus is savagely torn apart by maenads). Simultaneously, these high and remote places inspired awe and were believed to be untainted by the degeneracy and corruption of urban life. Here, people came face-to-face with deities (such as Pheidippides reportedly encountering Pan on Mt Parthenion (Herodotus 6.105). Aspromonte in particular is described only in Strabo, who drew extensively upon and augmented this classical literary tradition. Strabo's geography of empire implicitly promoted Augustus' project of imperial conquest and domination, and thus the taming of mountains to bring them under state control features strongly in Strabo's representations of mountains (König 2016). Although Strabo's itinerary takes the form of a sea voyage around the coast, the mountainous interior of the Aspromonte massif shaped his perception of Calabria's landscape, for example in portraying the cape of Leukopetra (modern Capo d'Armi) as the terminal point of the Apennines (Strabo 6.1.7). He refers specifically to the exploitation of forest products in the woodlands around Mammertion (Oppido Mamertina, Strabo 6.1.9), a territory inhabited by the Brettii, a people he considered as neither Greek nor Roman. This body of classical writing focused on mountains clearly had a significant impact on how classically educated travellers and writers in the nineteenth century viewed the mountains of classical lands (König and Hollis 2020: http://mountains.wp.st-andrews.ac.uk/).

\section{Roman}

Lowland Roman in the area includes a well-defined series of large farm sites (sometimes termed villas) located along the Roman coastal road, and a lessknown system of small, dispersed inland sites found up to $800-1000 \mathrm{~m}$ which probably represent agricultural activity areas which may or may not have been linked to larger villa-type sites. Above this altitude, Romans would have used the 
highland areas of Calabria, including Aspromonte, for forest resources, particularly timber and pitch (cf. Strabo 6.1.9; Pliny, Natural History XIV.127; and Cassiodorus for the sixth century) (Battista Sangineto 2013, 49, 77-80). However, their archaeological presence in the high mountains is elusive (see Fig. 2d, Fig. 3e). Two sites north of Africo at 753 and 1060m altitude yielded domestic assemblages (one with African Red Slip) and probably represent the most inland extension of small habitation sites. The furthest inland site, Porto Aposcipo (15 $\mathrm{km}$ inland, $1350 \mathrm{~m}$ ) may represent an industrial site of some kind.

\section{Medieval}

Settlement in the area changes dramatically between the late Roman period and the medieval period. As elsewhere in Italy, a long-drawn out shift took place between the sixth-nineth centuries; people moved away from coastal villages with the foundation of inland hilltop towns replacing them. The medieval landscape included a belt of towns surrounding Aspromonte, often including fortified castles (Coscarella 2016); these include Palizzi, Bova, Amendolea, Pentedattilo, Bagaladi, Montebello Ionico and Motta San Giovanni. Later medieval or early modern foundations include San Lorenzo, Condofuri, Africo, Roccaforte del Greco, and Roghudi. The oldest of these, Bova, probably dates to before the nineth century (Coscarella 2016), but most are later medieval or early modern foundations. There was also a dense religious landscape including rural churches and monastic sites. While traditional historiography ascribes the move from coastal to inland hilltop towns to an attempt to avoid malaria or raiders from North Africa and Sicily, such inland sites probably represent a new, inwardlooking political order. Yet the area formed part of feudal hierarchies stretching across Southern Italy, and it remained connected to long-distance trade networks along inland paths. It also formed part of far-reaching Byzantine and later Catholic ecclesiastical networks, and church and monastic sites up to $1000 \mathrm{~m}$ altitude are known from at least the eighth century onward.

Even with the new inland, hilltop towns, the inhabited medieval world remained mostly below $1000 \mathrm{~m}$ or so. At $900 \mathrm{~m}$, Bova is the highest town. Even the most inland towns known, such as Africo $(690 \mathrm{~m})$ and Roghudi $(450 \mathrm{~m})$ are lower than this, often located along river valleys that penetrate far inland among higher mountains; only Roccaforte del Greco (983m) is higher. Documentary sources suggest that the high mountains of Aspromonte provided forest products, notably large timbers for building, some of which were exported as far as Rome (Gregory I, letters 9.125.8 [Davis 2007: 34, 2010; Martyn 2004: 616-618]). But material evidence of medieval presence above $1000 \mathrm{~m}$ is thin. Within our survey area, only one find of medieval pottery was made (an isolated sherd at Mano di Madda, 1671m) (see Fig. 2e); just south our our area, in the Campi di Bova, an early medieval site is known at Travi $(1100 \mathrm{~m})$. Even considering that medieval pottery is often not distinctively identifiable, and that medieval settlement throughout this area seems to have been strongly concentrated around towns rather than dispersed in the countryside, use of the high mountains seems to have been light-touch rather than intensive. Probable medieval frequentation was found at Materazzelli $(1800 \mathrm{~m})$, in the highest, central mountains. Here, a scatter of late Roman/early medieval tile was found. It contained at least three separate types of tile (see Fig. 3f), suggesting materials had been scavenged or recycled from several places to create a 
small but well-built structure, possibly a small, isolated religious establishment such as a shrine or hermit's hut.

\section{Early Modern through Nineteenth Century}

There is no break in settlement between the medieval and modern periods; virtually all medieval towns remained centers of population up to the twentieth century. In the lowlands, settlement appears to gradually spread out more widely around centers, with more outlying sites and greater use of the coastline itself. Melito, the first town on the Ionian coast, is an eighteenth century foundation, there are a few eighteenth century houses and agricultural installations in Bova Marina, and catastal records indicate increasing use of lower foothills (Lazrus 2014). A similar trend toward broader landscape use appears in the high mountain survey data (see Fig. 2f). Five sites with pottery dating to between the early modern period and the earlier nighteenth century were found. They span all altitudes, up to the highest mountain zone (the highest is at $1833 \mathrm{~m}$ ). Several lie along crestline paths which are obvious transit routes in this terrain and which were used for later mule tracks; they may be artifact scatters left by travelers crossing the mountains. None were associated with architectural remains, and none suggest permanent settlement.

Aspromonte began to develop as a religious landscape in the early modern period, a use which continues today (Fig. 4). The epicenter was the Sanctuary of the Madonna delle Montagne at Polsi, located in an inaccessible valley east of Montalto (see Fig. 4d). While the Sanctuary was a medieval foundation, it was refounded and grew in the seventeenth-eighteenth centuries (Strangio 2011). By the early twentieth century, it was a place of pilgrimage for people living in towns around Aspromonte. Pilgrimage routes may have been associated with wayside shrines (see Fig. 4e), as well as with the monumental statue of Jesus atop Montalto, the highest peak in Aspromonte (see
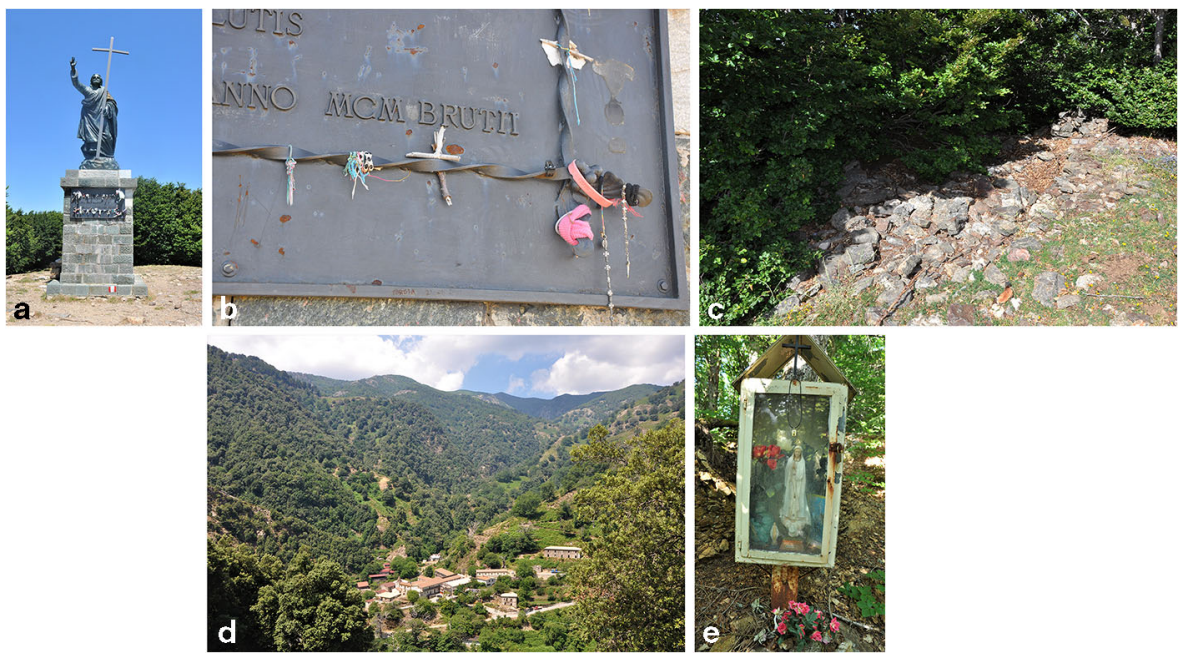

Fig. 4 The archaeology of a religious landscape. a. Statue of Jesus, Montalto peak (erected in 1900). b. Detail of recent votives placed on statue of Jesus, Montalto. c. Hut foundation, Montalto, possibly used by late ninteeth/early twentieth-century hermit. d. Pilgrimage destination, Sanctuary of Madonna di Polsi. e. Shrine along Gambarie-Montalto road, Tre Limiti 

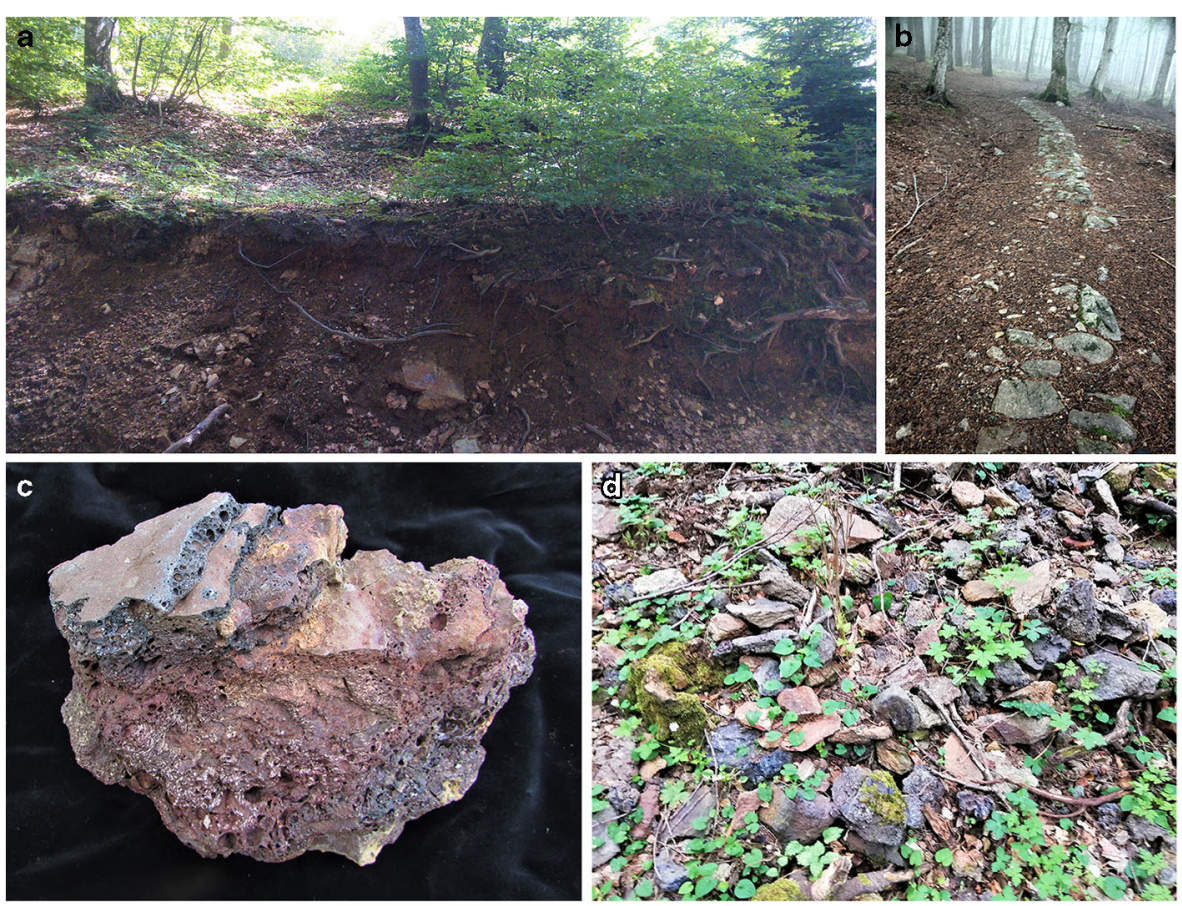

Fig. 5 Exploiting forest and mountain resources, medieval to modern. a. Charcoal burner's platform in road cut, northeast of Gambarie. Note levelled oval area and black charcoal-rich stratum just below surface in profile. b. Cobbled trackway for mule transport, southeast of Gambarie. Width of trackway is $90 \mathrm{~cm}$. c. Sporadic find, iron slag, Punto Telegrafo. d. Surface concentration of iron slag, Ferraina A

Fig. 4a, b). The remote mountains of Aspromonte were also supposedly the habitation of hermits seeking isolation (Oldfield 2014: 39-43; Ramsmeyer 2020: 401-403). While legends of such hermits date back to medieval times, one hermit is documented historically as living in a hut at Montalto in 1900, subsisting on alms from travellers (Picone Chiodo 2005: 27-30) (see Fig. 4c).

Three new activities also appear in the high mountains, probably between the fifteenth and nineteenth centuries. One is iron-working. Iron-smelting slag was found at eight locations scattered throughout the mountains (Fig. 5c). Two sites with substantial mounds of slag were found (Ferraina A and Ferraina C)(1417m), about $1 \mathrm{~km}$ apart in a valley with a perennial river (Fig. 5d); pXRF analysis confirms that both the slag and the local bedrock have a high iron content. While it is difficult to date these finds firmly and iron may have been worked in other periods, pottery from Ferraina A suggests that iron-working dates to the post-medieval period, probably sixteenthseventeenth centuries (A. Molinari, pers. comm.). This may imply itinerant, smallscale ironworkers moving between iron-rich rock outcrops, ideally close to charcoal sources. Although eighteenth-century writers mention copper extraction in the territory of Bova (Alagna 2005: 74) and copper and silver were mined in the hills southeast of Reggio in the seventeenth-eighteenth centuries (Clemente 2011), there is little historical note of an iron-working industry. Such diffuse, small-scale iron extraction would presumably have ended by the late nineteenth century, when improved transit would have made manufactured goods from outside the area more readily available. 
Secondly, three sawmills are listed on the 1870s maps (Piscopio, Pollio [located at or near the site of Porto Aposcipo], and Ferrughena [now Ferraina]). While the site of the first has probably been effaced by the modern Menta dam, neither of the others revealed any foundations or modifications related to water power or large industrial fixtures; these were probably human-powered saws. Nevertheless, while people had extracted large timbers from the mountains since Roman times, these are the first recorded substantial fixed installations for processing wood in the mountains, implying an increase in scale of exploitation and perhaps a reorganisation of timber production. Calabria supplied large timber for uses such as shipbuilding and railroad ties and these sawmills may have been tied into inter-regional commerce.

The most archaeologically obvious use of the forests in the later nineteenth century was charcoal-making (see Fig. 5a). Before the advent of coal and kerosene in the later nineteenth century, and electricity and gas in the earlier twentieth century, charcoal was in demand not only for industrial uses such as iron-smelting but also as a domestic fuel for heating and cooking in cities such as Reggio. Charcoal burners apparently worked in itinerant groups or encampments to cut wood, make charcoal and haul it on muleback to market. Particularly on the western side of Aspromonte, which is closer to the well-populated coastline around Reggio, entire hillsides are covered with the flat platforms on which wood was stacked in large mounds for carefully controlled burning. The platforms are readily identifiable oval or circular surfaces $5-8 \mathrm{~m}$ across cut into
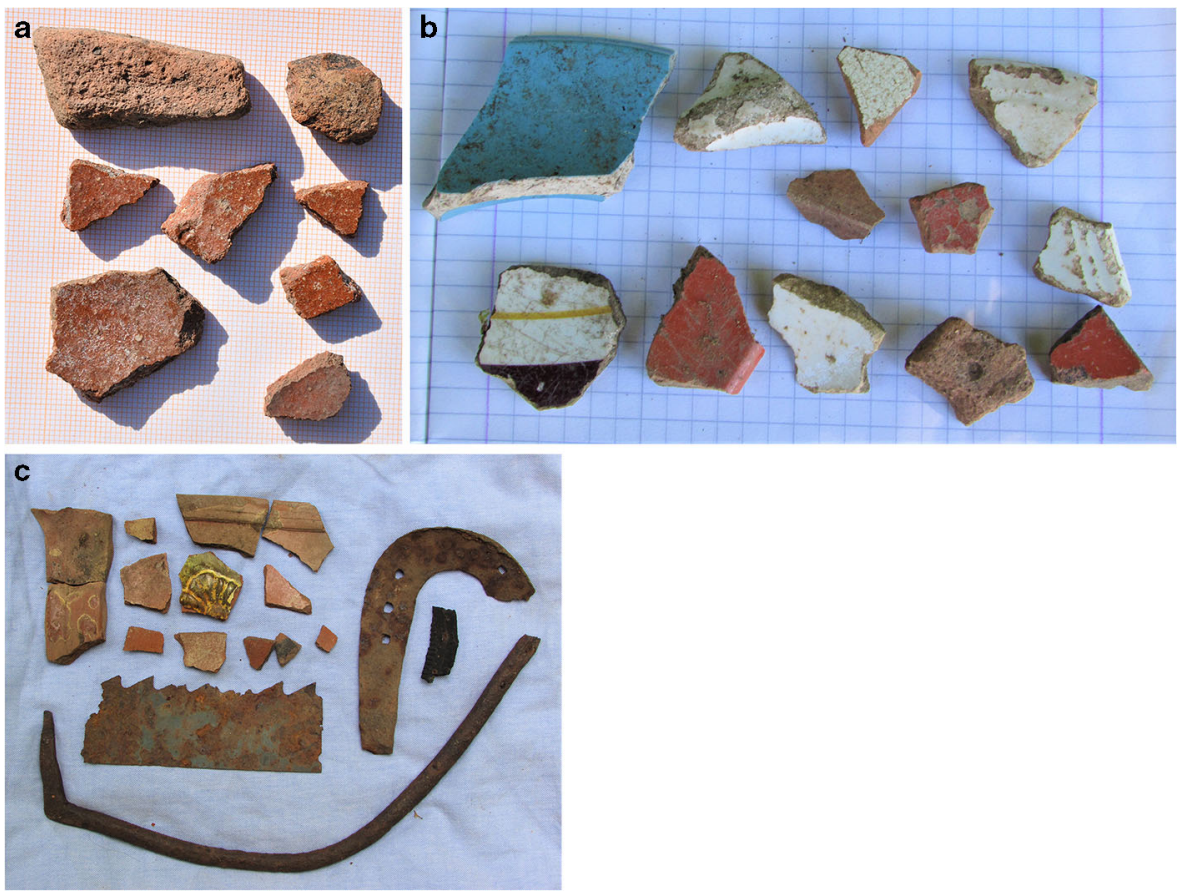

Fig. 6 Surface finds, nineteenth-twentieth century. a. Early-mid twentieth-century cooking wares, Tre Limiti. b. Mid-twentieth-century picnic assemblage, Serra Juncari. Findspot is in clearing adjacent to road to Madonna di Polsi, and finds probably represent picnics by pilgrimage outings. c. Mid-twentieth-century work crew assemblage, Giardini. Note mule or donkey shoe, hook possibly for handling timber, and fragment of cross-cut saw blade 
hillsides, often with charcoal fragments still visible (Fig. 6a). A parallel industry on a smaller scale was collecting snow and ice, although this remains archaeologically undocumented. Snow and ice were collected along the western slopes of Aspromonte during winters, stored in insulated pits until summer and carried down to Reggio and Messina to provide frozen desserts for city-dwellers.

Aspromonte was also covered by a network of constructed transit routes, in places quite dense. These took two forms. One was a network of narrow long-distance paths, sometimes sustained on slopes by small dry-stone retaining walls. Almost entirely now vanished in brush and forest, these connected inhabited centers across the mountains. The other was cobbled pathways. These were regular, carefully constructed paths, about $80 \mathrm{~cm}$ wide, made of a single layer of closely-set stones $15-25 \mathrm{~cm}$ in size (see Fig. 5b). Too narrow for wheeled vehicles or for herds, they clearly provided a fixed, solid surface for people and mules to travel upon. They followed obvious long-distance routes, at times coinciding with modern routes. Fragments of such paved trackways were found in 18 locations. The best-preserved pathway, running north-south across the lower slopes of Monte Basilico southeast of Gambarie, is traceable for 700m. Fragments along the principal trackway south from Materazzelli, the central topographic node of the high mountains, delineate a track extending southwards all the way to Bova some $18 \mathrm{~km}$ away. Other isolated finds of cobbled pavement suggest a network of routes throughout the mountains (cf. Picone Chiodo 2005: 150-1). Cobbled trackways of this kind are known throughout Mediterranean landscapes, and can serve a wide range of uses. These clearly are not for military or agricultural use; they are likely not for moving herds, as they are much narrower than tratturi paths known elsewhere in Italy, there seems to have been no formally organized system of large-scale transhumance they can be related to, and they seem unrelated to any other built features which might document such pastoralism. Instead, they seem to be infrastructure for mule traffic. Mules were the usual transport for traders. Such paths were already in existence elsewhere by the early nineteenth century. A British traveller, Arthur John Strutt, crossing a mountainous zone outside Palmi in 1841, noted "the remains of one of the steep, narrow, paved ways which were a few years ago, the only high roads in Calabria" (Strutt 1842: 219). In the absence of other organizations that might invest and organize such projects, they must have been constructed by municipal authorities, possibly using corvée labor during slow periods in the farming year. While they are hard to date precisely, they seem most likely to represent a short-lived, ambitious eighteenth-nineteenth century attempt at installing long-distance transportation infrastructure spanning the mountains. If so, it would have been fatally undercut by construction of coastal railroads (from the 1870s) and roads for wheeled vehicles (from the 1920s).

Overall, the eighteenth-nineteenth centuries witness an acceleration of activity in the mountains. This includes both low-intensity visits leaving small scatters of material, and short-lived or small-scale attempts to exploit timber and iron and to develop an infrastructure for communication and transport. This may represent an otherwise invisible sector of society; in traditional European rural societies in which status and social order were tied to land, semi-mobile people such as charcoal-burners were often considered a distinct bottom stratum of society, uncouth, rootless, and uncontrollable. While they are often mentioned anecdotally as picturesque examples of social outsiders encountered in the wild, there is almost no concrete historical evidence about them. 
What we have not found is evidence of intensified pastoralism, in the form of shielings, byres, pens, or similar installations. The signature of specialized transhumant pastoralism in European mountains is well known both ethnographically and archaeologically (Bartosiewicz and Greenfield 1999; Berruti et al. 2016; Carrer 2013, 2015; Carrer and Angelucci 2018; Christie et al. 2007; Mientjes 2004; Moe and Fedele 2019; Putzer et al. 2016; Stagno 2017; Visentin et al. 2016; Walsh et al. 2014). Such studies in the Alps, Pyrenees, and elsewhere have revealed the extensive infrastructure needed to support specialized pastoralism. While admittedly the archaeology of transhumant pastoralism can be elusive and historic shepherds may have had ephemeral huts of branches, a few stone-built pens are known in the area at lower altitudes, up to about 1400m (Picone Chiodo 2005: 131-40). No such structures were found in our survey. Relatedly, 1943 RAF aerial photos show clearly that areas below $1000 \mathrm{~m}$ were almost entirely deforested at that point, but areas between 1000 and $1400 \mathrm{~m}$ were about half covered in trees and areas above $1400 \mathrm{~m}$ remained thickly forested. While herds, particularly of cattle and goats, can forage in these forests and still do today, this does not suggest that the high mountains were intensively used for pasture. It seems likely that herding took the form of relatively short-distance movement within a few kilometers of settlements and was probably on a relatively limited scale and up to a limited altitude, unlike the seasonal long-distance movement of large herds known elsewhere in the Apennines and Alps.

There is also little evidence of any kind for historic brigandage. We would rarely expect to find archaeological evidence of banditry. Virtually every traveller in the area from the eighteenth century on mentions pervasive criminality in Calabria, above all attacks on travellers in rural areas, and it is clear that they are reporting fears of lawlessness shared by local residents everywhere. But while there are welldocumented historic accounts of brigands in central and northern Calabria (Ciconte 2011), there are few or none in Aspromonte. Toponyms here referring to brigands (Passo del Ladro, Baracca del Brigante, Cacciadiavoli, Monumenti di Nino Martino) all refer to a single semi-legendary sixteenth- century figure, Nino Martino, hardly implying rife bandit activity since then. The other famous outlaw of Aspromonte, Giuseppe Musolino (1876-1956, active around 1900), was not in fact a professional robber, but a fugitive from justice and prosecutor of personal vendettas (Ciconte 2011: 178-80). The fact that he was celebrated as "the last bandit in Aspromonte" probably owes less to his own exploits or to a continuous local industry of banditry than to the advent of mass media such as newspapers and to the reading public's expectation that the mountains of Calabria teemed with criminals.

\section{The Archaeology of the Later Nineteenth and Twentieth Centuries: A Ten-Fold Increase}

The overall landscape of southern Calabria transformed dramatically in the nineteenthtwentieth centuries. As elsewhere in Europe, population rose. This was accompanied by a shift to coastal settlement unseen since Roman times, encouraged by construction of coastal towns, highways, and railroads. By 1900, historic hill towns such as Bova were losing population and new coastal towns such as Bova Marina were booming. Other forms of internal migration included movement to newly developing farming areas 


\section{Gambarie Survey Finds \\ (Total survey areas, 195)}

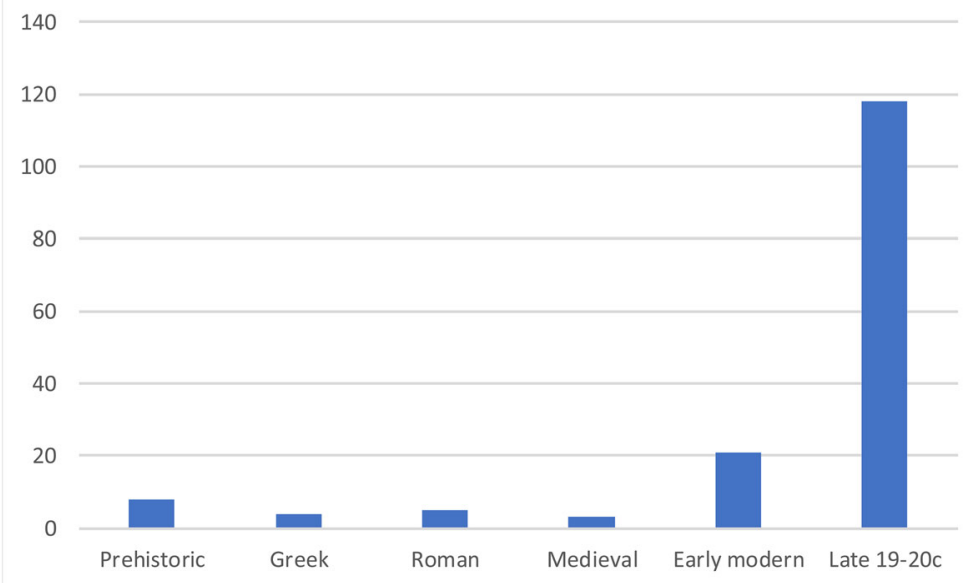

Fig. 7 Surface finds from field survey: findspots per period

such as irrigated citrus groves in lowland river valleys such as the San Pasquale valley in Bova Marina (Chesson et al. 2019). From the 1950s onward, the traditional world of peasant farming collapsed, as subsistence farming was undercut by cheap food imports and as rural people moved to towns, both nearby and in northern Italy, with paid jobs, schools, health care, running water, and electricity.

Paradoxically, even while the traditional rural landscape was contracting, use of Aspromonte's high mountains expanded dramatically in new directions. The only town above $1300 \mathrm{~m}$, Gambarie, was founded in the 1920s, numerous large-scale public works were begun, and a diffuse human presence in the landscape is much more visible archaeologically.

By far the largest number of finds in the highland survey date to the late nineteenth or twentieth centuries (Fig. 7, see also Fig. 2g, Fig. 6). Almost all were small scatters of pottery. Several kinds of assemblage were noted, probably corresponding to both distinct periods and uses (see Fig. 6). Terracotta fragments from water jugs and casserole-style cooking pots probably date to between the late 1800 s and the mid1900s, and may represent frequentation by charcoal burners, shepherds, and road and forestry workers (see Fig. 6a). Cups and plates of porcelain or white earthenware probably date mostly to the mid-later twentieth century, and may represent mostly family-style picnics (see Fig. 6b). By the later twentieth century, most such wares were superseded by plastic vessels or disposables, and ubiquitous finds of Peroni beer bottles and small fires indicate frequentation both by forestry work crews and by hikers and picnickers. Other assemblages were probably related to mid-twentieth-century work crews (e.g. Fig. 6c).

The human presence behind these finds probably represents a mixture of activities. Political, recreational, and industrial uses of the landscape are discussed below. In addition, as population pressure increased, and before the abandonment of the countryside, farming encroached on higher altitudes. In the survey area, no agricultural 
settlements are noted on the 1870 IGM maps. By the time of the 1943 RAF photographs and the 1957 IGM maps, farmhouses are indicated in the upper Amendolea valley north of Roghudi up to about $1200 \mathrm{~m}$. Similarly, terracing around Gambarie indicates farming in more level areas up to $1400 \mathrm{~m}$. The highest agricultural installation known is the ruined foundations of a farmhouse with terracing and relict fruit trees, observed in field survey at Martorano (1465m). Such marginal, settled areas probably had a halo of areas utilized for pasture and forest resources of $1 \mathrm{~km}$ or more, with hunters and mushroom collectors ranging further afield. Some herding activity undoubtedly took place. For instance, Alvaro (1955) draws an ethnographic picture of the lives of small-scale, sharecropping shepherds in the mountains in the 1920s, and the few "traditional" shepherd enclosures known (Picone Chiodo 2005: 131-40) probably date to the last century or so. Both charcoal burning and snow collection continued and indeed may have intensified in the twentieth century, until they were put out of business by newer technologies (gas, electricity, and refrigeration), probably between the 1920s and 1950s; local residents have described older relatives engaged in charcoal-burning before the Second World War. People from towns around Aspromonte took part in pilgrimage, often on foot, along mountain paths to the sanctuary of the Madonna at Polsi. Near the main pilgrimage route along the watershed of the mountains, a monumental statue of Jesus was installed on the highest point atop Montalto (1960m) in 1900 (see Fig. 4a), and pilgrimage may have increased with motor transport when this route was paved in the 1920s. Indeed, survey found several shrines with pilgrimage mementos from the early 2000s, all concentrated along this road (see Fig. 4e).

\section{Landscape Projects of the State: Political Control, Roads, and Economic Development}

It is axiomatic that the modern state must control all of its territory, and the cartographic mandate is essential to this mission. The 1870s Istituto Geografico Militare maps followed the unification of Italy almost immediately. They charted areas never systematically surveyed before, including Aspromonte. Systematically collated knowledge enabled political control and economic planning (for instance, the 1870s maps formed the basis for planning development projects such as road-building and drainage in 1910s and 1920s). It also helped define political boundaries, and it flattened differentials between local knowledge and the synoptic, impersonal eye of the state. The project of defining territory continued on a concrete, local scale as well. The archaeological footprint of cartography, still visible deep in the forests, consists of boundary stones (Fig. 8a), trigonometric points (Figs. 8b, c), and rusting, kilometers-long wire fences marking the boundaries between adjacent comuni. A US Air Force trigonometric point on the easternmost end of Montalto ridge shows the cartographic imperative tied into politics on an international scale. Nor did Aspromonte escape Cold War politics. At Nardello (1800m), a US Air Force base provided a radar station for monitoring air traffic throughout the Central Mediterranean (Fig. 9). The Nardello base was in operation from the mid-1960s to the mid-1980s. Its archaeological remains include perimeter fencing, an observation tower, offices, supply tanks, and the massive concrete blocks upon which radar dishes were mounted. 

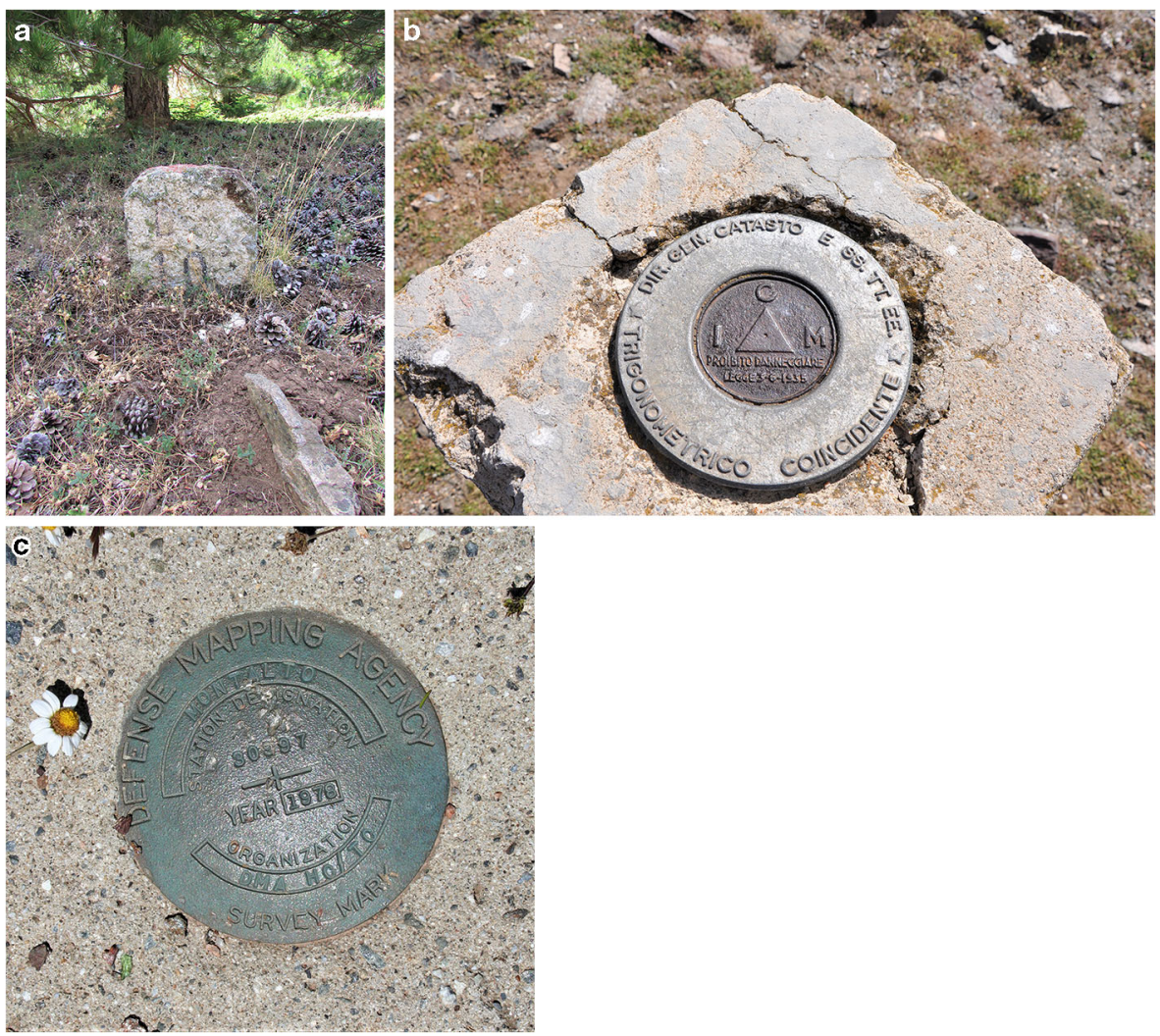

Fig. 8 The archaeology of cartography. a. Boundary marker between territories of two comuni. b. Istituto Geografico Militare survey datum point, Montalto peak. c. US Air Force survey datum point, eastern end of Montalto summit

The village of Africo (Fig. 10) shows state intervention of a different kind. A remote and poverty-stricken hamlet of 1500-2000 people without roads, schools, or medical care, in the 1920s it was made famous throughout Italy by the social campaigner U. Zanotti-Bianco (2009) as an exemplification of the squalor and deprivation of the

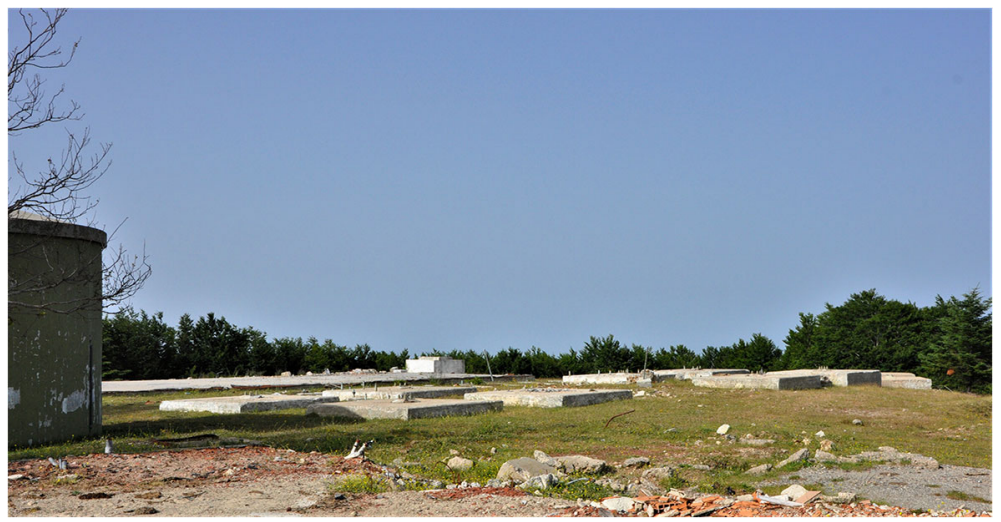

Fig. 9 Nardello US Air Force radar station. Square concrete platforms served as bases for radar dishes 

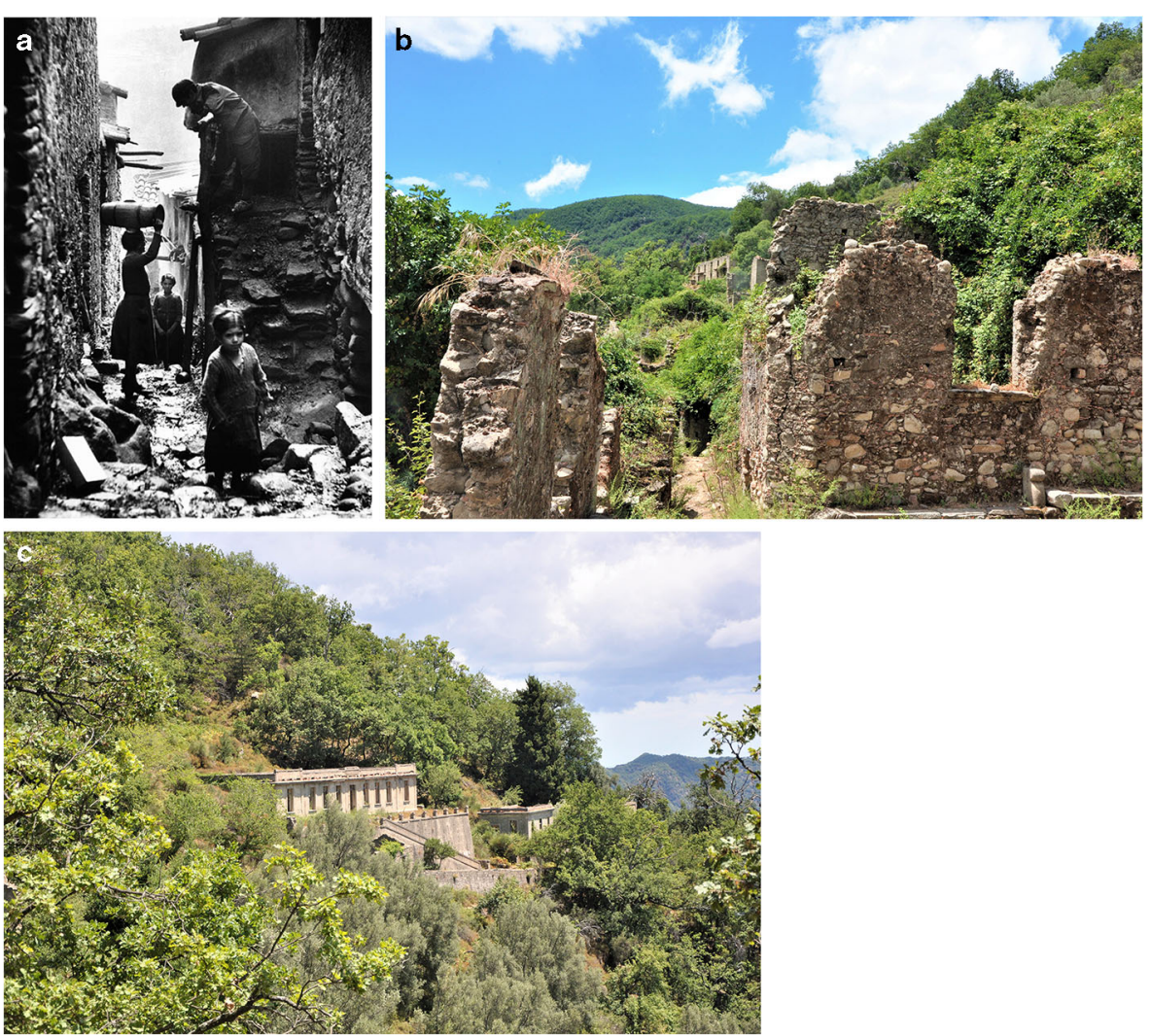

Fig. 10 Rural poverty in the mountains: the town of Africo (abandoned 1951). a. A street in Africo, photographed in 1948 by photographer Tino Petrelli (image; Valentino Petrelli (C) Archivio Publifoto Intesa Sanpaolo - Regione Lombardia / Museo di Fotografia Contemporanea; all rights reserved). b. A street in Africo, photographed in 2016. c. 1940s attempts to improve social conditions in Africo: the elementary school (left) and police station (right)

south; this was confirmed by photographer Tino Petrelli's images in 1948 (Fig. 10a). Shoeless, illiterate peasants living like beasts proved a glaring provocation to a regime devoted to portraying Italy as a modern nation, and in the 1930-40s Africo received a new primary school, a new church and (following anti-state demonstrations there [Palamara 2015]) a police station (Fig. 10c). Then, in 1951, a landslide wiped out the only road connecting the village to the outside world, and the government solved the problem a different way, forcibly removed the entire population, who spent four years in temporary barracks before moving to a newly founded town, Africo Nuovo, on the coast (Palamara 2015; Stajano 2015). The new buildings, along with the rest of the village, were left to decay (Figs. 10b, c).

The largest single project of the state was building roads (Fig. 11), which are often the largest datable historic landscape feature (Ruiz 2016) Already before the First World War, planners acting on a 1908 parliamentary directive to develop the south had projected roads to be built into the mountains (Mollica 1991). In a 1920s climate of large-scale public works, they began to act, building the first long-distance coastal road since Roman times. In the high mountains, the two key roads, a north-south one across 

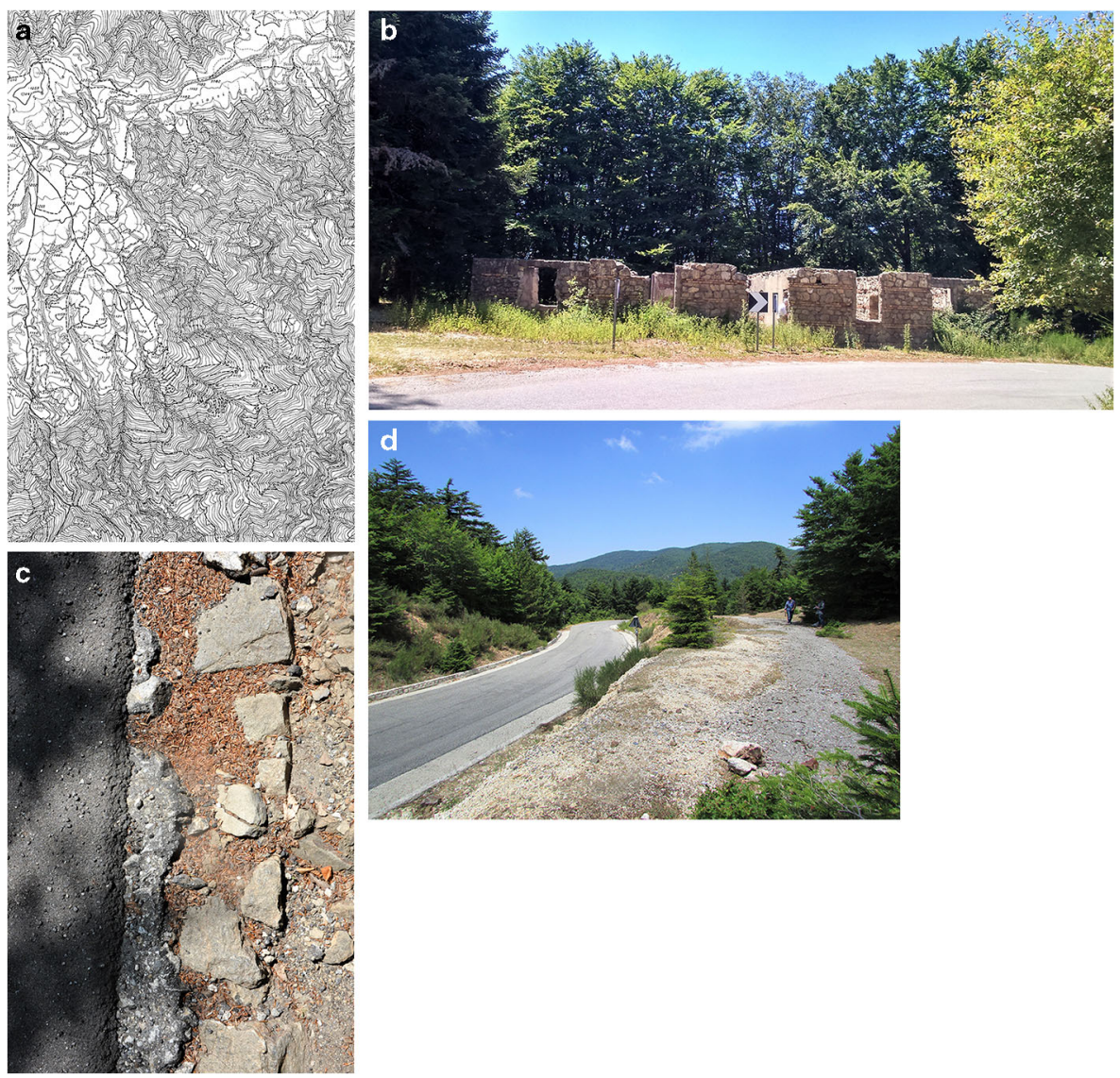

Fig. 11 The archaeology of roads. a. Dense network of mule paths recorded on IGM 1:10000 maps (1957; area shown here is Campi di Bova, along the road from Bova to Roghudi). Paths and trails are indicated by dashed lines; almost all have vanished in forest in the last 70 years. b. Mid-century roadworks base with barracks, offices, and truck ramp, Sella Entrata. c. The Gambarie-Montalto road: superimposition of 1920s, 1950s, and 1990s paving. d. Road to Diga del Menta dam: disused 1950s-60s paved road (right) replaced by 1980s-90s road adapted to lower gradients and gentler curves (left)

the western edge of Aspromonte from Melito to Sant'Eufemia and an east-west one running along the crest of the mountains to connect Gambarie to Montalto, did not lead to centers of population; they were solely for opening up the mountains. Building them involved massive work by gangs armed with trucks, picks and shovels, working from bases such as the now-ruined mid-century barracks and workshop complex at Sella Entrata (Fig. 11b). Archaeological inspection shows the multi-generational stratigraphy of these roads, with a durable 1920s stratum of stone paving covered by buckling 195060 s concrete and then by potholed 1980-90s tarmac (Fig. 11c). Roads sometimes followed earlier paths and trails, particularly along obvious routes such as crestlines, but they frequently modified them, introducing curves and switchbacks for motor vehicles where mules had negotiated steep grades, and they sometimes carved out entirely new routes (Fig. 11d). Road-building succeeded magnificently in making mountains accessible to workers and visitors in motor vehicles. As part of their 

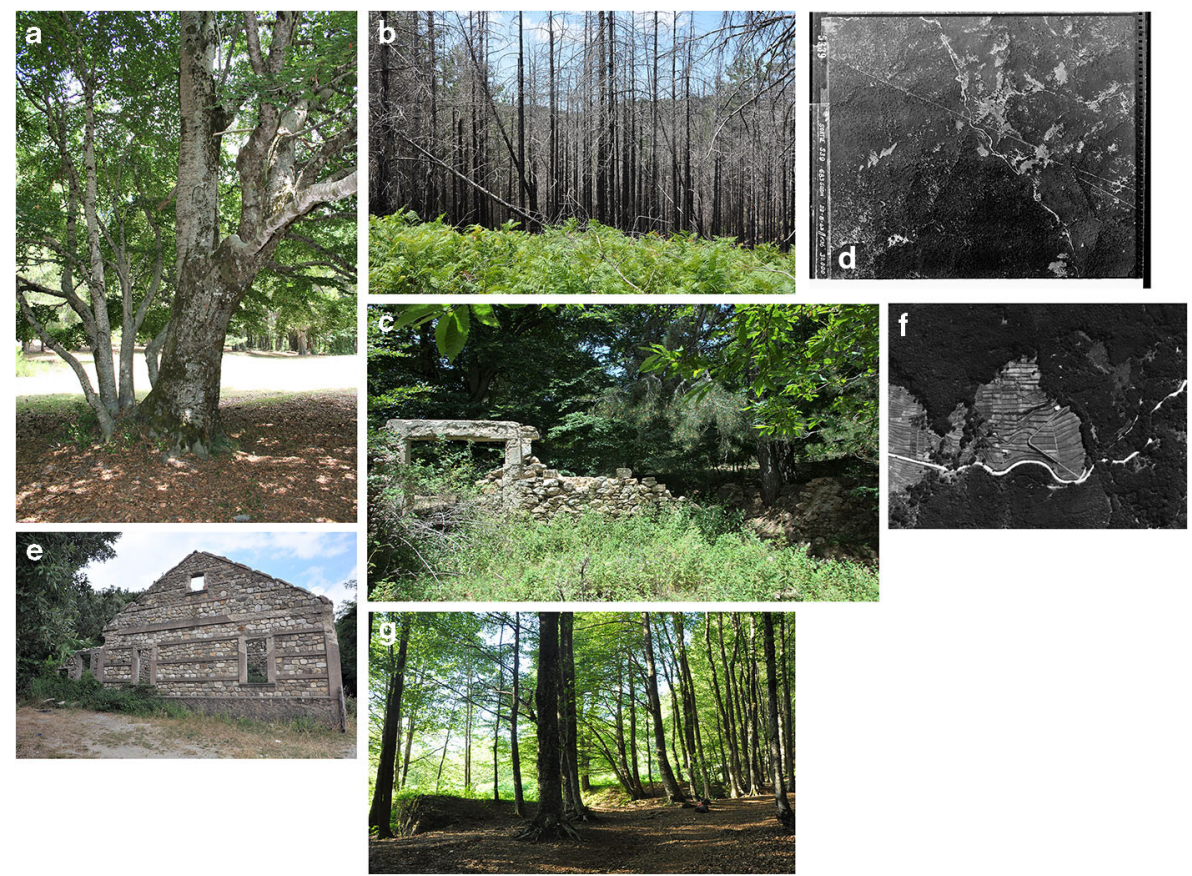

Fig. 12 The archaeology of forest development. a. Beech tree, main trunk probably ca. 1930s, coppicing probably ca. 1980-90s (ca. 1500m). b. Mono-species pine plantation, ca. 1200m, 1960s; photo taken following recent forest fire. c. Ruins of mid-century water-powered sawmill complex with cisterns, machine areas, office and storerooms, Pantanizza. Area shown here is entrance to sawing room. d. RAF reconnaissance photo of Materazzelli area, 1943. Teleferiche (cable systems for transporting cut trees to sawmills) are visible as long linear straight cuts through forests; two run into the Materazzelli work area from the Pietra Capella/ Giardini area to the southeast, and one runs in from the Acque delle Face area to the northwest. From Materazzelli timber would have been transported out on trucks along the main Gambarie-Montalto road. Image courtesy of National Collection of Aerial Photography, Edinburgh. e. Decommissioned 1950s-60s Forestry Corps house with distinctive masonry, Casa Romeo. f. Campo Sperimentale (experimental farm) for developing essential oils industry, located at the junction of the Gambarie-Bagaladi road and the Gambarie-Montalto road, as visible in RAF reconnaissance photos from 1943. Image courtesy of National Collection of Aerial Photography, Edinburgh. g. The same, visited in 2016. Beech trees growing in the terraces are at least 70 years old, suggesting that the Campo Sperimentale went out of use no later than sometime in the 1940s

civilizing mission in an area notoriously considered lawless, they also allowed the forces of order to move police or army units rapidly. Roads also reoriented understanding of the landscape. The 1957 IGM maps record a dense, fine-grained network of mule tracks gradating into local roads. Ground-truthing these today shows that some former roads (such as the Strada Comunale extending northwards from Nardello to Puntone Scirocco) have become simple mountain tracks, and much of the dense network of former trails has vanished entirely, reclaimed by forests (Fig. 11a). Roads had a paradoxical effect. They effectively concentrated travellers, replacing a dense capillary network of tracks accessible to local knowledge with fewer, more obvious and more travelled routes accessible to outsiders. Even as they made the heart of the mountains more accessible, they also rendered other areas within the mountains more abandoned. 
The major twentieth-century industry in the mountains was forestry. Starting even in Fascist times, deforested areas were systematically replanted. Beech plantations were created in many cleared areas above $1300 \mathrm{~m}$ (Fig. 12a). Pines and occasionally chestnuts were planted between $1000-1400 \mathrm{~m}$ in the $1950 \mathrm{~s}-80 \mathrm{~s}$ in a period style of densely monocropping fast-growing trees (Fig. 12b). Forestry crews also built and maintained forest infrastructure, including unpaved access roads, paths, fences, and springs. Private companies paid for rights to cut timber in delimited areas.

The archaeological and historic footprint of forestry is clear:

- Patterns of tree growth in beech groves clearly show cutting major trunks at generational intervals since at least the nineteenth century (see Fig. 12a).

- Several dozen sheds or work structures are shown throughout Aspromonte on 1957 IGM maps, with some remaining on 1997 IGM maps. Ground-truthing many of these shed locations shows that virtually all of these structures have vanished entirely, with little trace even of foundations. The biggest complex, of five huts, is shown at Materazzelli, the center of the mountains where several tree-lifts converged; archaeological inspection located a shallow possible foundation trench for only one. This suggests that these structures were not simply abandoned habitations or agricultural buildings, which would likely have had substantial stone-built foundations. Instead, they were probably light temporary structures associated with the forestry corps which were dismantled and moved when no longer needed. Such distributed camps probably collected trunks for transport down to sawmills rather than sawing them up on the spot.

- Three mid-twentieth-century sawmills were noted on 1957 maps (Sant'Antonio, Cufalo, and Pantanizza). All were located along the western margin of Aspromonte, on or near a major road. Cufalo was a small, simple mill, probably powered by a gas engine; today, only concrete footings for equipment and a few fragments of masonry remain. Pantanizza, in contrast, was an elaborate complex (Fig. 12c). Two kilometers of buried ceramic piping $15 \mathrm{~cm}$ in diameter brought water downhill from a perennial spring to fill a series of cisterns. Water flow from these cisterns powered heavy saws mounted on concrete pillars. The complex also included storage and loading areas and a house for workers. Based on its masonry style and design, the complex operated for perhaps two decades between the 1930s and 1950s. The system of sawmills located in forestry areas did not endure long. More recent sawmills, using diesel or electric saws, are located in towns at lower altitudes such as Santo Stefano d'Aspromonte; trunks are transported to them using heavy trucks equipped with lifting arms.

- A related technology was the teleferica. This was a cable-car system which transported industrial loads such as tree trunks along a cable strung between support poles. It was invented during the First World War to carry supplies to Italian soldiers fighting against the Austrians in the high Alps, and later adapted for mountain timber-harvesting. Five of these appear clearly as linear cuts through the forest in 1943 RAF aerial photos of Aspromonte (see Fig. 12d); they are also recorded on the 1957 IGM maps, which mistakenly identifies them as aqueducts. One fed the sawmill at Sant'Antonio; and several fed the work area at Materazzelli. Just outside our survey area, others were built to transport trees to a sawmill in San Luca. They were apparently dismantled when the intensive phase of logging in the 
1940s and 1950s finished; forest has regrown over their paths, and no trace of them remains on the ground today.

- A more substantial series of about 20 permanent houses to provide shelter for forestry workers was built throughout the mountains (Picone Chiodo 2006). Most were built in a distinctive mid-century style of masonry alternating brick and stone, with reinforced concrete structural elements; this is found only in publicly constructed building and was apparently intended both to be ornamental and to resist earthquakes (Fig. 12e). These structures provided living space, though without electricity; water came from a nearby spring. A few remain in use, sometimes by hikers as well as forestry workers (e.g. Giardini; S. Leo). Most are now derelict; since the 1960s, with mass automobile ownership, forestry workers generally return home from work each day rather than staying in mountain camps.

While logging remains ongoing today, the most active phase seems to have been between the 1930s and 1950s, when much of the old-growth forest was probably cut. Indeed, the largest beech trunks now commonly found in Aspromonte are generally about 80 years old, which would date them to the phase of regeneration following this period. What is most striking about mid-century forestry is how integrated a system it seems to have been, with a wave of investment in purpose-built sawmills, aqueducts, camps, and transport systems which were used for a brief period and then decommissioned. The scale and uniformity strongly suggests it was a state-sponsored project.

Aspromonte was also home to other industrial and infrastructure projects, both successful and unsuccessful. The spring-rich mountains east of Gambarie have a broad system of short-distance buried aqueducts to provide water for the town (including one small hydroelectric plant), and similar systems bring water to other towns such as Roccaforte del Greco. On a larger scale, the Diga di Menta dam collects water from several streams into an artificial lake to supply drinking water for the city of Reggio. A satellite transmission tower at Puntone Scirocco dates to the 2000s. In contrast to these successful initiatives, a conclusively failed project is the Campo Sperimentale, or experimental farm (see Fig. 12f, g). This was an extensive (ca. $0.5 \mathrm{~km}^{2}$ ) area south of Gambarie which was cleared and terraced to jump-start a new industry, growing aromatic plants to extract their essential oils. A 1930s project clearly visible on the 1943 aerial photos, it must have been discontinued after only a short time, as much of its extant terracing is now covered with mature beech and chestnut trees whose rings show them to be a good 70-80 years old. This is the archaeology of failed development projects, a a phenomenon widespread across of Southern Italy and Sicily: factories which never went into production, cultural centers built without roads leading to them, state-of-the-art tourist infrastructure left to rust, and similar political white elephants (or cattedrali nel deserto, "cathedrals in the desert") which served mostly to harvest the funding. Most such projects date to the 1960s or later; the Campo Sperimentale shows that the social impulse underlying them goes back as far as development projects themselves.

Overall, there was a huge pulse of development in Aspromonte in the 1920s and 1930s; road-building, forestry, and town-building (see below) were all major Fascist period projects. Yet overt Fascist ideology seems relatively muted. One inscription with Fascist iconography dates a monumental fountain at Tre Aie to "An. X" or "Year 10 of 


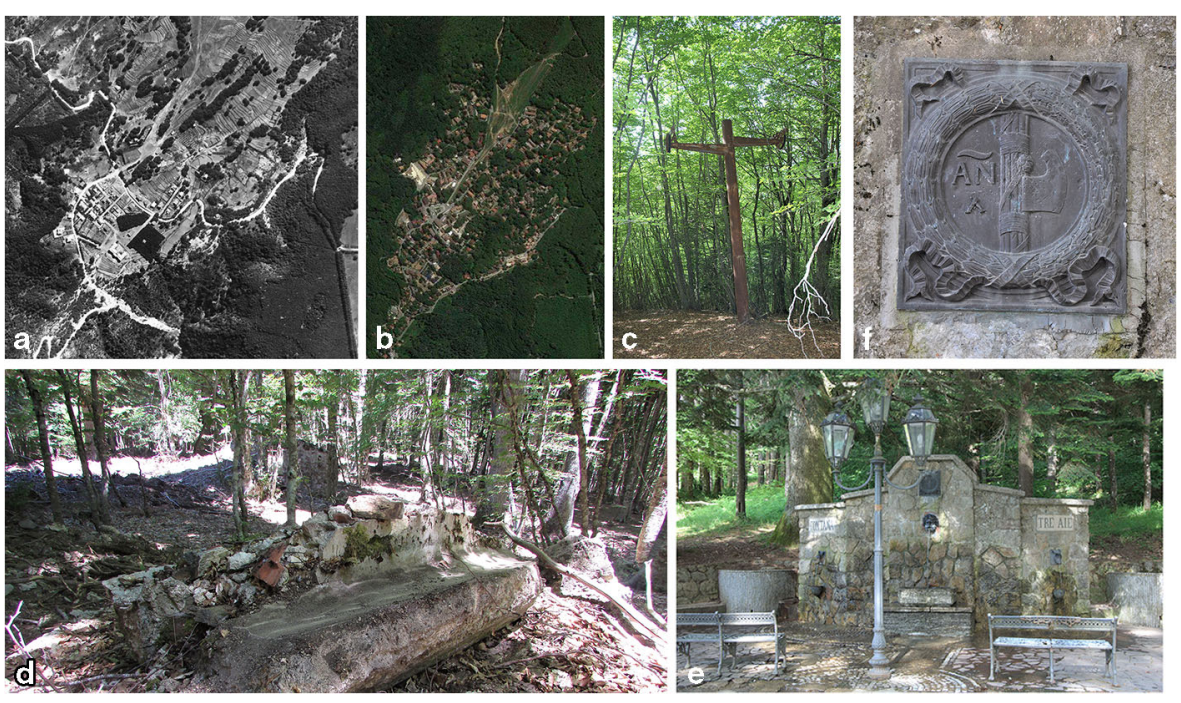

Fig. 13 Developing a recreational landscape. a. Gambarie in 1943 (RAF reconnaissance photo). The large Ushaped building is the Albergo Grande; the two other major installations, the railway workers' union holiday house, and the government employees' union holiday house, are located just outside of town. Besides these, the town contains about 20 houses. The ski slope runs uphill north-northeast of town. Image courtesy of National Collection of Aerial Photography, Edinburgh. b. Gambarie in 2019 (Google Earth). The ski slope remains in the same place, but a ski lift has been added east of it. c. First-generation ski lift pylon, now enveloped in forest, Gambarie. d. Ruins, Colonia di Chiera camp. e. Tre Aie monumental fountain, south of Gambarie. f. Inscription, Tre Aie monumental fountain

the Fascist Era" (e.g. 1933) (Fig. 13). But even considering what may have been removed since 1943, there is little of the grandiosity or material propaganda which marks Fascist public installations in cities such as Reggio or even in some rural areas (Samuels 2010). Perhaps creating an ambitious, modern mountain landscape and simply providing jobs was enough to create a local power base.

\section{Landscape Projects of the State: Inventing a Recreational Landscape}

Meanwhile, during the twentieth century, a completely new kind of landscape was created in Aspromonte: the recreational landscape. Its ideological roots were twofold. One source can be traced to the Romantic fascination with nature, mountains, and "wild" landscapes. This is evident in Romantic landscape painting from the early nineteenth century onward. Calabria was noted for its romantic landscapes (Gaetano 2015); an early local vector was Edward Lear (1964), who toured southern Calabria sketching rugged landscapes in 1842 . From the mid-nineteenth century onward, the romantic attraction to mountains fostered Alpine tourism and mountain climbing. The Club Alpino Italiano (CAI) was founded in Torino in 1863 to further mountaineering and skiing. By the 1920s, city dwellers from Reggio were driving up to the nascent settlement at Gambarie to ski, and the Reggio branch of the CAI was founded in 1932 (Arillotta 2013; Meduri and Pontecorvo 2005). Aspromonte does not offer many peaks suitable for technical mountaineering of the ropes-and-pitons variety, and the CAI's 
early activities were focused mostly on skiing, with a parallel focus on hiking emerging only later. The second ideological source was the 1920s concept of healthful, physically, and spiritually restorative summer holidays for urban masses in rustic "natural" surroundings. This widespread concept was often coupled with political or religious ideologies; it underwrote scouting movements, summer camps outside American cities, the socialist "rambler" movement in 1930s Britain, and National Socialist youth camps in Germany. In 1930s Italy, such summer camps were often combined with religious or labor organizations; the Fascist government had seaside holiday camps aimed at developing Fascist youths. Like Italian "colonie" in general, they typically did not feature wilderness camping, but had hostel-style residential bases for a variety of outdoor activities.

Aspromonte's new recreational landscape was invented through several developments (see Fig. 13).

- Gambarie, an entirely new town, was created in the 1920-30s (Meduri and Pontecorvo 2005). It is located on the western edge of Aspromonte's central massif at the best point of entry from Reggio. It was created essentially as a recreational base for skiers. Its original 1930s core involved a large, formal hotel, a few smaller lodgings, and two large camps or resorts tied to labor unions (one for railroad workers and one for employees of public administration) (see Fig. 13a). Maps and architectural styles suggest steady growth since the 1950s, with hotels, a central piazza, and many seasonally occupied houses (see Fig. 13b).

- The first ski slope was constructed across a previously terraced mountainside east of Gambarie in the 1920s, and the first ski-lift was constructed in the 1950s, appearing on the 1957 IGM maps but not on the 1943 RAF air photos. Since then, there has been a continual extension of skiing infrastructure. Our archaeological survey has located pylons from a small, first-generation ski-lift rusting in the forest (see Fig. 13c); a second, disused lift remains still standing. A major pulse of building seems to have happened from the 1990s on, with EU funding; at present four ski slopes have been cleared, extending $5 \mathrm{~km}$ east of Gambarie.

- A publicly funded, fully equipped hostel was built at on the ridge between Nardello and Puntone Scirocco in the 1990s; it was in operation for only 2-3 years. Covered with graffiti, it remains mothballed today.

- Summer camps elsewhere in the mountains are represented by the Colonia di Chiera $(1567 \mathrm{~m})$. Known historically only from a name on the 1957 IGM map, only ruined foundations remain today (see Fig. 13d). Archaeologically it is a complex of five small buildings, apparently with different uses (kitchen, bathhouse, and probably an office/caretakers' house, communal building, and dormitory). A small, rustic complex, it probably could not have hosted more than a dozen people in a relatively rudimentary style. It dates to the mid-twentieth century, and was probably in use only for a short time, to judge from mature trees growing up inside building foundations. It presumably entertained families of some organization's employees; it was probably connected with the Pantanizza sawmill, which was contemporary, built in the same style and only $1 \mathrm{~km}$ away.

- Creation of an extensive recreational landscape is evident in installations throughout the mountains. Installations include formal picnic areas, signage for tourists, wooden fencing along some trails, and small fountains at perennial springs. The 
earliest datable such infrastructure is the monumental fountain at Tre Aie, at a picnic area $1.5 \mathrm{~km}$ south of Gambarie, dated to 1933 (see Figs. 13e, f). The summit of Montalto boasts a monument in the form of a compass dial pointing the direction to landmarks erected by the Rotary Club; the trail to the peak boasts a set of marble steps installed in a moment of ambition and now in disarray. While it is difficult to date many of these installations, some are demonstrably recent (dated inscriptions on Forestry Service-erected fountains are rarely earlier than the 1990s), and most probably date to the last 20 years. The Parco Nazionale dell'Aspromonte (Aspromonte National Park) was formed in 1994 with the mission of managing and protecting the natural environment of the area and of encouraging nature and cultural tourism (Bevilacqua and Picone Chiodo 1999), and most of these installations probably fall under its aegis.

- Again, these installations are accompanied by a diffuse archaeological record, comprising small scatters of debris (principally pottery and glass) associated with picnics. The ceramics are typically mid-to-late twentieth-century tablewares. In contrast with pottery scatters of undecorated terracottas, which are often found in quite remote locations, these seem mostly distributed in clearings along roads, particularly along the Gambarie-Montalto road, and similar material is also found at formally defined picnic areas. More recent archaeological finds attesting recreational use up to the present (i.e., litter) is also widespread.

Cumulatively, these projects create a new kind of landscape in Aspromonte, a landscape understood not in relation to its residents, economic uses, or relationship to the villages encircling it, but entirely as a new kind of place: a recreational and spiritual resource for urbanites. Creating such a landscape was a goal explicitly stated when the Parco Nazionale $d$ ell'Aspromonte encompassing most of this area was founded in 1994. But it clearly had been growing since the 1920s, with a major expansion in the post-war period. What Aspromonte has to offer for urbanites is complementarity or difference, to be enjoyed in a temporary sojourn. In fulfilling this role, "nature" is Aspromonte's strong suit; in contrast to the crowded, noisy cities and coastal strip, the forested mountains seem to exemplify "nature" at its most pristine. Cultural tourism, another desideratum and one upon which the area's hope for economic survival rests, is more of a challenge. The high mountain area lacks demonstrable historic traditions, visible human occupation, and visitable monuments other than the summit of Montalto and the sanctuary at Madonna di Polsi. Filling this void, books, websites, and tourist materials generalize the folklore and peasant traditions of towns around the margins of the mountains such as Bova and Santo Stefano, extending them to the high mountains and recycling images and legends of bandits and shepherds.

\section{Modern, but Structurally Archaic: Inventing Ancient Mountains}

This research supports two main conclusions. One is empirical. Historical and contemporary archaeologists have established how archaeological evidence can ground continuous narratives of social change in the recent past. This is all the more so in areas such as Aspromonte, where the twentieth-century textual record leaves many gaps, and for classes of people under-represented or excluded in the textual record. The material evidence 
before our eyes is a key source even for recent decades. Taking such an approach, the picture that emerges reveals a new history of landscape use in Europe's mountains. Elsewhere in Italy, and indeed in southern Europe, there is archaeological evidence that humans used high mountains in many periods from the Bronze Age through medieval times, particularly as seasonal pastures in transhumant systems (Bartosiewicz and Greenfield 1999; Berruti et al. 2016; Carrer 2013; Carrer and Angelucci 2018; Christie et al. 2007; Mientjes 2004; Putzer et al. 2016; Visentin et al. 2016; Walsh et al. 2014). But in Aspromonte, this was not the case. People frequented the mountains in all periods, but they never supported extensive occupation. In most periods, use of the mountains above about $1000 \mathrm{~m}$ seems always to have been transitory and light on the ground. Finds probably reflect not inhabitation but short-term forays for using specific mountain resources. Only in the Archaic, Classical, and Hellenistic periods were scattered initiatives made to actually inhabit the mountains permanently, particularly through agricultural settlement of small, fertile highland plateaux, which left a series of fortified rural sites between 1100-1300m altitude. Our survey has shown that less formalised Greek use extended well above this zone, probably to exploit specific mountain resources such as pitch.

Why was Aspromonte not used more intensively as some other high mountain areas? The answer lies in the specifics of regional geography. An island of rugged terrain entirely surrounded on all sides by a thin margin of poor communities, it was never important for strategic political reasons. It had no major transit routes to furnish livelihoods either for commercial transport or for predatory bandits. And it did not have a dense, extensive or prosperous lowland area to generate the lowland end of producers or consumers to anchor systems of mass transhumance or of industrial exploitation.

Instead, the real development of the high mountains began only in the last two centuries. In more recent periods, the high tide of traditional peasant farming carried nineteenth-early twentieth-century farming to about $1300 \mathrm{~m}$ at the very highest in a few places, but such use contracted sharply in the twentieth century. There was also a slow crescendo of sporadic, small-scale uses (iron-working, charcoal-making, timber-harvesting, construction of communication routes for pack animals), probably reflecting growing population density in the surrounding lowlands (for instance, most of the charcoal made in the nineteenth-early twentieth centuries was probably destined for the urban markets of Reggio).

There is an increasing archaeology of nineteenth-twentieth-century social change. Elsewhere in Italy, research has highlighted historic changes in the 1800s and 1900s due to factors such as depopulation, road-building, shifts in productive strategies, and workers' aspirations to escape poverty (Pluciennik et al. 2004; Stagno 2017). Pastoral systems changed as well (Carrer 2015; Carrer and Angelucci 2018; Mientjes 2004; Moe and Fedele 2019; Stagno 2017; Walsh et al. 2014). These studies provide a comparative context highlighting the strong variability. The fate of mountains and pastoral systems in the twentieth century depended to a great extent upon their local context. Sometimes mountain use increased, particularly when they were tied to specific lowland markets. Sometimes they became increasingly specialized, or changed focus, for example with the development of heavy industry in some Alpine valleys and of long-distance transit routes in others. Sometimes, especially when long-distance transit routes and urban markets were lacking, they were abandoned as people sought easier and more prosperous lives elsewhere. But nowhere were twentieth-century 
shepherds simply avatars of an unchanging tradition. Among this panorama, Aspromonte's trajectory is unique. With little history of intensified pastoralism, the twentieth-century development of the mountains is due almost entirely to state intervention (cf. Kuijt et al. 2015) for a parallel case in a marginal zone of western Ireland). The state tackled the mountains as a challenge to its political control, and as an affront to modernity; these impetuses resulted in a wide range of development projects. Although not all projects visible on the ground can be closely dated, there seem to have been several distinct pulses of activity. The first major effort was in the Fascist period, including key projects such as road-building, forestry, and recreational development. A period of continuous steady extension of these projects followed throughout the postwar period. Most recently, there has been a burst of highly visible but sometimes incompleted projects funded by European Union money in the 2000s. Development involved re-envisioning the mountains in three distinct ways: politically, economically, and as a recreational landscape. The development of Aspromonte responded to centralised plans for political control of all the territory of the state through cartography, accessibility, police, and defence organizations. Economic development was founded upon infrastructure such as road-building and water management. It involved a few tangential projects, mostly short-term and unsuccessful, such as experimental farms. But its major focus was forestry, with reforestation and the harvesting of timber - activities which have left a broad and varied archaeological footprint on the landscape. The other focus of twentieth-century state and institutional projects was invention of an entirely new kind of landscape, the recreational landscape. Responding to a pan-European nineteenth-twentieth-century Romantic quest to seek "nature" in inaccessible mountains, and to a twentieth-century ideology of healthy, spiritually regenerative mass recreation in natural settings for urban dwellers, the invention of a recreational landscape resulted in an equally pervasive archaeological footprint, which ranges from surface scatters left by short-term visitors to defunct summer camps and ski lifts. The result was a new practical understanding of the mountains as a place conceptually interdependent with the lowland world but defined as its opposite.

The second striking implication of this work concerns chronogeography. Any landscape requires a history; landscapes have to be fitted within a global narrative to be understood. Aspromonte was frequented in all periods, but in ways which left little obvious historical traces. Both ancient and medieval writers developed mythologies of mountains as wildernesses, often as places close to the supernatural. For nineteenthand twentieth-century writers, the mountains appeared devoid of towns, religious sites, medieval castles, and Classical ruins, and thus afforded no substantial hooks for observers to hang narratives upon. In many ways, it provided them with a tabula rasa. It could equally well have been understood as a brand-new landscape, something made possible for the first time by twentieth-century progress. But it was structurally archaic in the logic of modernity, which supplied a ready-made temporal geography founded upon a crowded, fast-changing modernity defined in lowland centers. Visible dichotomies such as lowland vs. highland, connected vs. isolated, populated vs. unpopulated, and state-controlled vs. liminal were extended to encompass historical change vs. timelessness and the present vs. the past. To take an obvious example, trees were equated with "nature" and hence assumed to be prior to history; no traveller ever asked whether the forests themselves had a history, rather than being unchanging or primeval. 
In such a logic, mountains were pre-destined to represent the past. In a crowded modern world, Aspromonte's very emptiness was seen as evidence of its unchanging antiquity.

When Norman Douglas walked across Aspromonte in 1912 admiring the trackless forests and the archaic shepherds, the forests were not trackless. They had been mapped systematically by the Italian government 40 years earlier; they supported industries of independent, small-scale entrepreneurs supplying charcoal and ice to cities; there was a nascent timber industry; and government plans for their development were already afoot. Descending from Montalto to Bova, Douglas walked down stretches of cobbled mule path; had he inquired about its history, he would have learned that it had been constructed probably less than a century before. Nor were the shepherds archaic; the specific form of animal ownership and rights to pasture they used had probably changed dramatically in the nineteeth century with Napoleonic and postRisorgimento land reforms. Their economic life (as described in Alvaro's (1955) Gente in Aspromonte) was a form of pastoral sharecropping made possible by the nineteenthcentury sale of rights to common land to wealthy landowners. They could have been read as small-scale, low-capital entrepreneurs, or as a rural proletariat. But Douglas found what he sought. Like other modern observers from outside the mountains, steeped in a Classical tradition equating mountains with pastoral vistas and adding a modern, lowland-centered narrative of civilization and order, he chose to see the mountains as timeless, and to understand the shepherds he encountered ahistorically as legacies of an unchanging antiquity rather than as individuals as enmeshed as himself in a changing world. Indeed, when locals regaled him with tales of Giuseppe Musolino, the "last bandit" of Aspromonte, Douglas understood him as an avatar of an archaic violent justice; yet it would be equally accurate to see Musolino as somebody whose criminality was created by the intersection of social hierarchy, the judicial system, and the new mass media which enveloped him in notoriety.

Douglas left the most detailed period travelogue of Aspromonte in any language, but he was not alone. Both foreign and Italian travellers throughout the nineteenth and twentieth centuries persistently constructed the Calabrian landscape using the same logic, seeking a landscape of unchanging traditions and archaisms. The area was seen primarily in terms of things it lacked: roads, law, and modernity (Nucera and Nucera 2012). People and landscapes encountered there were automatically classified as survivals of ancient traditions, by definition anachronistic in the modern world. Indeed, when Douglas returned in the 1920s and found that you could now ascend to Montalto by the newly-built road from Gambarie, he reacted with a mournful nostalgia, lamenting the passing not only of an archaic order but of the heroic solo trekking it afforded time travellers such as him (Douglas 1938: v). In some ways, this encapsulated the paradox of the high mountains. Once one ventured into the forests above the inhabited zones, the landscape was essentially created by modern interventions; but as soon as modern observers arrived there, they made the mountains ancient.

Acknowledgments We thank our funders, particularly the National Endowment for the Humanities and the Cambridge Humanities Research Grants. Base-map data for the GIS maps (Figure 1b, 2) were derived from OpenStreetMap (https://openstreetmap.org/) data under the Open Database Licence via Geofabrik (https://geofabrik.de/) and CORINE Land Cover (https://land.copernicus.eu/) created with funding by the European Union; elevation data are used from TINITALY/01 (Tarquini et al.). We are grateful to Giovanni Iiriti, to Mimmo Nucera for hosting us in Gambarie and for much local information, and to the members of the Reggio Calabria branch of the Club Alpino Italiano. The staff at the National Collection of Aerial Photography 
in Edinburgh helpfully supplied RAF reconnaissance photos. We are grateful to the Archivio Storico Intesa Sanpaolo, Archivio Publifoto and Museo di Fotografia Contemporea, Milan, for use of Figure 10a. David Redhouse kindly provided the GIS maps. Marcos Martínon-Torres provided expert advice upon iron-working slag, Alessandra Molinari and Adele Coscarella provided invaluable advice on historic pottery identifications, and Francesco Carrer provided important information on the archaeology of pastoralism. We also thank our sturdy and intrepid survey crew members: Jeremy Bennett, Mo Farr, Kevin Kay, Larry Lane, Nicholas Robb, William Robb, Isabelle Rubin, and Jess Thompson.

Open Access This article is licensed under a Creative Commons Attribution 4.0 International License, which permits use, sharing, adaptation, distribution and reproduction in any medium or format, as long as you give appropriate credit to the original author(s) and the source, provide a link to the Creative Commons licence, and indicate if changes were made. The images or other third party material in this article are included in the article's Creative Commons licence, unless indicated otherwise in a credit line to the material. If material is not included in the article's Creative Commons licence and your intended use is not permitted by statutory regulation or exceeds the permitted use, you will need to obtain permission directly from the copyright holder. To view a copy of this licence, visit http://creativecommons.org/licenses/by/4.0/.

\section{References}

Agostino, R. and Sica, M. (2009). Palazzo: Una struttura fortificata in Aspromonte. Rubbettino, Soveria Mannelli.

Alagna, D. (2005). Bova: Città nel Regio di Napoli nella Calabria Ulteriore (1775). Nuove Edizioni Barbaro, Delianova.

Alvaro, C. (1955). Gente in Aspromonte. Garzanti, Milano.

Arillotta, F. (2013). Il CAI a Reggio Calabria. Kaleidon, Reggio Calabria.

Bartosiewicz, L. and Greenfield, H. (1999). Transhumant Pastoralism in Southern Europe: Recent Perspectives from Archaeology, History and Ethnology. Archaeolingua, Budapest.

Battista Sangineto, A. (2013). Roma nei Bruttii: Studi e ricerche sulle antichità calabresi . Ferrari, Castrovillari.

Berruti, G. L. F., Bertè, D. F., Caracausi, S., Daffara, S., Ferreira, C., and Garanzini, F. (2016). New evidence of human frequentations in the western Alps: The project "survey Alta Valsessera (Piedmont-Italy)." Quaternary International, 402, 15-25.

Bevilacqua, F. and Picone Chiodo, A. (1999). Il Parco Nazionale d'Aspromonte. Rubbettino, Soveria Mannelli.

Bonfà, S. (2015). La Dea Madre in Aspromonte: Immagini di un Mito. Amazon E-book.

Brizzi, M. and Costamagna, L. (2010). Il sito fortificato di Serro di Tavola. In H. Treziny (Ed.), Grecs et indigènes de la Catalogne à la mer noire: Actes des rencontres du programme européen Ramses2 (20062008), pp. 581-594. Centre Camille Jillian, Errance.

Buxton, R. (2016). Mount Etna in the Greco-Roman imaginaire: culture and liquid fire. In Sluiter, I. and McInerney, J. (eds.), Valuing Landscape in Classical Antiquity: Natural Environment and Cultural Imagination. Brill, Leiden, pp. 25-45.

Carrer, F. (2013). Archeologia della pastorizia nelle Alpi: Nuovi dati e vecchi dubbi. Preistoria Alpina 47: 4956.

Carrer, F. (2015). Herding strategies, dairy economy and seasonal sites in the southern Alps: ethnoarchaeological inferences and archaeological implications. Journal of Mediterranean archaeology, 28: $3-22$.

Carrer, F. and Angelucci, D. E. (2018). Continuity and discontinuity in the history of upland pastoral landscapes: the case study of Val Molinac and Val pore (Val di sole, Trentino, eastern Italian Alps). Landscape research, 43: 862-877.

Chesson, M. S., Ullah, I. I. T., Ames, N., Benchekroun, S., Forbes, H., and Garcia, Y. (2019). Laborscapes and archaeologies of sustainability: early globalization and commercial farming in the San Pasquale Valley, Calabria, Italy from AD 1800-2018. Journal of Mediterranean Archaeology, 32: 32-62.

Christie, N., Beavitt, P., Santonja, J. G., Senís, V. G., and Seguí, J. (2007). Peopling the recent past in the Serra de L'Altmirant: Shepherds and farmers at the margins. International Journal of Historical Archaeology, 11: $304-321$. 
Ciconte, E. (2011). Banditi e Briganti: Rivolta Continua dal Cinquecento all'Ottocento. Rubbettino, Soveria Mannelli.

Clemente, G. (2011). Archeologia mineraria di età borbonica nella Calabria meridionale: le minieri del Valanidi a Reggio Calabria e Motta san Giovanni tra Settecento e Ottocento. Archeologia post-medievale, 15: 81-90.

Coscarella, A. (2016). Bova e lo Stretto tra archeologia e storia. Università della Calabria, Cosenza.

Davis, R. (2007). The Lives of the Eighth-Century Popes (Liber Pontificalis): The Ancient Biographies of the First Ninety Roman Bishops to AD 715. Liverpool University Press, Liverpool.

Davis, R. (2010). The Book of Pontiffs (Liber Pontificalis): The Ancient Biographies of the First Ninety Roman Bishops to $A D$ 715. Liverpool University Press, Liverpool.

Douglas, N. (1938). Old Calabria. Oxford University Press, New York.

Foxhall, L., Robb, J., Yoon, D., Gillings, M., and Taylor, J. (2010). La frequentazione greca nell'area di Bova Marina e nel Comune di Bova. In Caridi, G., Cozzetto, F., and Nucera, C. G. (eds.), Bova: Storia di una Comunità Greca della Calabria, Apodiafazzi, Bova, pp. 19-40.

Foxhall, L. and Yoon, D. (2016). Carving out a territory: rhegion, Locri and the households and communities of the classical countryside. World archaeology, 48: 431-448.

Gaetano, R. (2015). Sull'Orlo dell'Invisibile: Il sublime nella Calabria Dei Viaggiatori. Laruffa, Reggio Calabria.

Gassiot Ballbè, E., Clemente Conte, I., Mazzucco, N., Garcia Casas, D., Obea Gómez, L., and Rodríguez Antón, D. (2016). Surface surveying in high mountain areas, is it possible? some methodological considerations. Quaternary international, 402: 35-45.

Grimaldi, S., Bang-Andersen, S., Carrer, F., Crotti, P., Della Casa, P., and Fontana, F. (2016). Human occupations of mountain environments. Quaternary International, 402: 2-4.

J. König (2016). Strabo's mountains. In Sluiter, I. and Mcinerney, J. (eds.), Valuing Landscape in Classical Antiquity: Natural Environment and Cultural Imagination. Brill, Leiden, pp. 46-49.

Kuijt, I., Conway, M., Shakour, K., Mcneill, C., and Brown, C. (2015). Vectors of improvement: the material footprint of nineteenth- through twentieth-century Irish National Policy, Inishark, county Galway, Ireland. International Journal of Historical Archaeology , 19: 122-158.

Lazrus, P. K. (2014). Reacting to the powers that be: investigations of a Calabrian, post-medieval community. International Journal of Historical Archaeology, 18: 65-99.

Lear, E. (1964). Edward Lear in Southern Italy: Journal of a Landscape Painter in Southern Calabria and the Kingdom of Naples. William Kimber, London.

Martyn, J. R. C. (2004). The Letters of Gregory the Great. Pontifical Institute of Medieval Studies, Toronto.

McInerney, J. and Sluiter, I. (eds.) (2016). In Valuing Landscape in Classical Antiquity: Natural Environment and Cultural Imagination. Brill, Leiden.

Meduri, G. and Pontecorvo, G. (2005). Gambarie in bianco e nero: Dalle origini agli anni settanta. Città del Sole, Reggio Calabria.

Mientjes, A. (2004). Modern pastoral landscapes on the island of Sardinia (Italy): recent pastoral practices in local versus macroeconomic and macro-political contexts. Archaeological Dialogues, 10: 161-190.

Moe, D. and Fedele, F. G. (2019). Alpe Borghetto: origins and evolution of a summer farm area in the Italian Central Alps based on vegetation history and archaeology, Neolithic to present. Vegetation History and Archaeobotany, 28: 141-162.

Mollica, E. (1991). La «Relazione Ruini» del 1913 Sugli Interventi Speciali in Calabria: Aspetti Economici e non nella Valutazione dei Programmi di Investimento. Rubbettino, Soveria Mannelli.

Nucera, A. and Nucera, E. (2012). Viaggio nell'Aspromonte Greco: Sguardi e Memorie di Uomini venuti dal Nord. Città del Sole, Reggio Calabria.

Oldfield, P. (2014). Sanctity and Pilgrimage in Medieval Southern Italy, 1000-1200. Cambridge University Press, Cambridge.

Palamara, B. (2015). Africo dalle Origini ai Nostri Giorni. Laruffa, Reggio Calabria.

Picone Chiodo, A. (ed.) (2005). In Segni dell'uomo nelle Terre Alte d'Aspromonte. Edimedia/Rubbettino, Pescia.

Picone Chiodo, A. (2006). Guida ai Caselli Forestali della provincia di Reggio Calabria . Club Alpino Italiano, Reggio Calabria.

Pluciennik, M., Mientjes, A., and Giannitrapani, E. (2004). Archaeologies of aspiration: historical archaeology in rural Central Sicily. International Journal of Historical Archaeology, 8: 27-65.

Putzer, A., Festi, D., Edlmair, S., and Oeggl, K. (2016). The development of human activity in the high altitudes of the Schnals Valley (South Tyrol/Italy) from the Mesolithic to modern periods. Journal of Archaeological Science: Reports, 6: 136-147. 
Ramsmeyer, V. (2020). Questions of monastic identity in medieval southern Italy and Sicily (c. 500-1200). In Beach, A. J. and Cochelin, I. (eds.), The Cambridge History of Medieval Monasticism in the Latin West, Volume 1: Origins to the Eleventh Century. Cambridge University Press, Cambridge, pp. 399-414.

Ruiz, R. (2016). Modern road archaeology: identification and classification proposal. International Journal of Historical Archaeology, 20: 437-462.

Salerno, A. and Pessina, A. (2004). Le asce in pietra levigata della Calabria nelle Collezioni del Museo Pigorini. Atti, Riunione Scientifica dell'I.I.P.P. 37: 765-772.

Samuels, J. (2010). Of other scapes: archaeology, landscape, and heterotopia in fascist Sicily. Archaeologies: Journal of the World Archaeological Congress, 6: 62-81.

Stagno, A. M. (2017). Archaeology and history of an uncertain space: temporary cultivation between collective practices and private appropriation (Basque Country, 15th-20th c.). Quaderni Storici, 52: 499-533.

Stajano, C. (2015). Africo. Il Saggiatore, Milano.

Strangio, A. (2011). La nuova guida del Santuario di Polsi. Nuove Edizioni Barbaro, Delianuova.

Strutt, A. J. (1842). A Pedestrian Tour through Calabria and Sicily. T. C., London.

Tarquini, S., Isola, I., Favalli, M., Mazzarini, M., Bisson, M., Pareschi, M. T., and Boschi, E. TINITALY/01: a new Triangular Irregular Network of Italy. Annals of Geophysics, 50: 407-425.

Visentin, D., Carrer, F., Fontana, F., Cavulli, F., Cesco Frare, P., Mondini, C., and Pedrotti, A. (2016). Prehistoric landscapes of the Dolomites: survey data from the highland territory of Cadore (Belluno Dolomites, northern Italy). Quaternary International, 402: 5-14.

Visonà, P. (2009). Oppido Mamertina: Ricerche Archeologiche nel Territorio e in contrada Mella. Gangemi, Rome.

Visonà, P. (2010). University of Colorado/University of Kentucky excavations at Monte Palazzi, Passo Croceferrata (Grotteria, Calabria): the 2005, 2007, and 2008 field seasons. Fasti Online: https://www. fastionline.org/docs.FOLDER-it-2016-351.pdf.

Walsh, K., Court-Picon, M., De Beaulieu, J. L., Guiter, F., Mocci, F., and Richer, S. (2014). A historical ecology of the Ecrins (southern French Alps): archaeology and palaeoecology of the Mesolithic to the medieval period. Quaternary International, 353: 52-73.

Zanotti Bianco, U. (2009). Tra la perduta gente. Rubbettino, Soveria Mannelli.

Publisher's Note Springer Nature remains neutral with regard to jurisdictional claims in published maps and institutional affiliations.

\section{Affiliations}

\section{John Robb ${ }^{1}$ - Meredith S. Chesson ${ }^{2} \cdot$ Hamish Forbes $^{3} \cdot$ Lin Foxhall $^{4} \cdot$ Helen

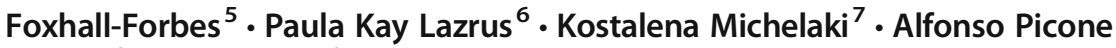 Chiodo $^{8}$ - David Yoon ${ }^{9}$}

1 Department of Archaeology, University of Cambridge, Cambridge, UK

2 Department of Anthropology, University of Notre Dame, Notre Dame, IN, USA

3 Department of Archaeology, University of Nottingham, Nottingham, UK

4 School of History, Languages and Cultures, University of Liverpool, Liverpool, UK

5 Department of History, University of Durham, Durham, UK

6 College of Liberal Arts and Sciences, St. John's University, New York, NY, USA

7 School of Human Evolution and Social Change, Arizona State University, Tempe, AZ, USA

8 Facoltà di Agraria, Università Mediterranea di Reggio Calabria, Reggio Calabria, Italy

9 American Numismatic Society, New York, NY, USA 